\title{
Foredeep vs. wedge-top facies trends and hierarchical thickness distributions, Pennsylvanian Atoka Formation, Ouachita Mountains, USA
}

\author{
Pengfei Hou*, Zane R. Jobe, Lesli J. Wood \\ Department of Geology and Geological Engineering, \\ Colorado School of Mines, Golden, Colorado, USA
}

\begin{abstract}
:
Topographic confinement can impose significant control on depositional styles of deepwater fan deposits. Currently, there is a lack of quantitative documentation on the spatial variation of topographic confinement in segmented deepwater basins. Herein, we investigated the Pennsylvanian Lower Atoka Formation in the Ouachita Mountains, south-central the United States which is a fine-grained submarine fan system deposited on the active Ouachita Fold and Thrust Belt. The basin is divided by two distinctive depozones that are laterally confined: foredeep and wedge-top, both of which are primarily sourced from the east. We quantitatively compared the lithofacies, architectural elements, and hierarchical thickness distributions of turbidite lobe deposits among proximal foredeep, distal foredeep, proximal wedge-top, and distal wedge-top depozones. The proximal foredeep and wedge-top show identical lithofacies compositions and thickness distributions of lobe deposits. However, the foredeep shows a significant proximal-distal decrease in sand-prone deposits and thicknesses of lobe deposits, whereas the wedge-top show little to no such changes. We demonstrated that the complex topography and stronger lateral confinement in the wedge-top depozone is the dominant
\end{abstract}


control for this difference. The signal of topographic confinement increases hierarchically from bed to lobe scales because these deposits tend to stack more vertically rather than switching horizontally (or compensationally) due to confinement. The results have implications for predicting hydrocarbon reservoir distribution, recognizing the degree of confinement, and refining the depositional reconstruction of analogous laterally-confined turbidite systems.

Keywords: confinement, Lower Atoka, Ouachita Mountains, turbidite, facies hierarchy, thickness distribution

\section{Introduction}

Basin confinement is known to modify the sediment distribution patterns for turbidite systems and impose uncertainties in reservoir prediction for hydrocarbon exploration (Felletti, 2002; Sinclair and Tomasso, 2002; Booth et al., 2003; Lomas and Joseph, 2004). The style and degree of basin confinement of turbidity flows is often described as confined (contained or ponded), semi-confined (laterally or frontally confined), and unconfined (Pickering and Hiscott, 1985; Patacci et al., 2015; Tökés and Patacci, 2018). Identification of confinement in a turbidite system requires evidence of the turbidity flow interacting with the basin margin. In many cases, basin confinement is simply inferred from tectonic reconstructions, or from spatial variations of facies characteristics. Morphometric techniques have been broadly employed in characterizing turbidite systems with varying degrees of confinement (Deptuck et al., 2008; Covault and Romans,

2009; Prélat et al., 2010; Nyberg et al., 2018; Pettinga et al., 2018). Unfortunately, in 
most outcrop studies which provide excellent sedimentologic and facies scale details, lateral extent is typically very limited. In such cases, the statistical analysis of turbidite thicknesses has proven useful for illustrating confinement on deep marine deposits (Chen and Hiscott, 1999b; Felletti and Bersezio, 2010; Pantopoulos et al., 2018). Such statistical analysis of turbidite thickness distributions has been focused on the bed scale (Carlson and Grotzinger, 2001; Talling, 2002; Sylvester, 2007). Turbidite bed thickness is primarily controlled by the flow size, efficiency, and rheology of the turbidity currents (Sinclair and Cowie, 2003; Ja'Aidi et al., 2004). The bed thickness distribution has been used to characterize the sub-environments in turbidite systems (Chen and Hiscott, 1999a; Carlson and Grotzinger, 2001; Chakraborty et al., 2002; Talling, 2002; Bersezio et al., 2005; Clark and Steel, 2006; Marini et al., 2016b; Palozzi et al., 2018). However, bed thickness distribution can also be modified by the proximity to the sediment source (Bersezio et al., 2005; Pantopoulos et al., 2018) and topographic confinement of the depositional system (Malinverno, 1997; Sinclair and Cowie, 2003; Felletti and Bersezio, 2010).

Turbidite lobe deposits are sensitive to external forcing (Tőkés and Patacci, 2018) and exhibit compensational stacking patterns in a hierarchical manner (Mutti and Normark, 1987; Deptuck et al., 2008; Straub and Pyles, 2012). Therefore, it is advantageous to explore the influence of confinement on turbidite lobe deposits with a hierarchical scheme (Deptuck et al., 2008; Prélat et al., 2009), which consists of three scales in this work: bed, lobe element, and lobe (Sections 3.3.2 and 4). We focus on characterizing lobe deposits with different degrees of lateral confinement, which is common for deepwater foreland basin (Mutti et al., 2003; DeCelles, 2012), rift basin (Ravnås and 
Steel, 1998; Gawthorpe and Leeder, 2000), and deepwater fold and thrust belt (Morley et al., 2011). In an unconfined setting, lobe-deposit bed thicknesses tend to display significant decrease from proximal to distal (Fig. 1A) or from axial to marginal locations (Walker, 1978; Bouma et al., 1985; Mutti, 1985; Spychala et al., 2017). This proximaldistal variation corresponds to the relative high bed thinning rate due to flow expansion of unconfined turbidity currents (Fryer and Jobe, 2018; Liu et al., 2018; Tőkés and Patacci, 2018). The distribution of bed thicknesses is expected to display limited dispersion due to the lack of flow thickening mechanism. Assuming all other external forces remain the same, the bed thicknesses of confined lobe deposits are expected to show a similar proximal-distal trend but to a lesser extent, because confined turbidity currents have limited flow expansion and are forced to thicken, which will result in lower bed thinning rates over the same distance in the deposits (Sinclair and Cowie, 2003; Marini et al., 2015; Fryer and Jobe, 2018; Liu et al., 2018; Tőkés and Patacci, 2018). Confined lobe deposits are expected to show greater thickness distributions and dispersions (Fig. 1B), although it can be modified by various degrees of bypass, erosion, and bed amalgamation (Jobe et al., 2017). Similar statistical contrasts between unconfined and confined settings are expected for hierarchically larger (lobe element and lobe) deposit thickness datasets (Fig. 1C), as documented by morphometric dimensions (Pettinga et al., 2018). However, the translation of confinement signatures from bed to lobe scales as well as their spatial variations within a basin is not well understood.

In this study, we investigated the lithofacies trends and thickness distributions hierarchically of the less confined foredeep and the more confined wedge-top turbidite systems of the Pennsylvanian Lower Atoka Formation in the Ouachita Basin in south- 
central United States (Walthall, 1967; Sprague, 1985; Houseknecht, 1986; Coleman, 2000; Arbenz, 2008). The objectives of this study are to a) describe the longitudinal facies trends of the parallel foredeep and wedge-top turbidite systems, b) quantify the thickness distributions of turbidite lobe deposits in both depozones with a hierarchical scheme, c) characterize the degrees of lateral confinement using statistical comparison of the thickness distributions, and d) assess the usefulness of thickness distributions in deciphering the record of basin confinement in hierarchically classified lobe deposits.

\section{Geological Setting}

\subsection{Tectonic history}

The Ouachita Mountains in the south-central United States is the outcrop expression of the Paleozoic Ouachita Fold and Thrust Belt (OFTB) along the southern Laurentia (Fig. 2A and 2B). The OFTB is part of the Appalachian-Ouachita-Marathon orogenic belt that formed during the Laurentia-Gondwana collision (Thomas, 2004, 2011). The sedimentary fill of the Ouachita Basin accumulated along a passive margin beginning in the Cambrian and transitioned into an east-west elongate remnant ocean basin in Pennsylvanian time. It is bounded by the Laurentia Craton to the north and the Sabine Terrane to the south (Mickus and Keller, 1992; Keller and Hatcher, 1999). The basin was established by continental rifting that occurred during the late Proterozoic to Cambrian, and the basin was closed during the Late Pennsylvanian due to the collision of the Sabine Terrane (Houseknecht, 1986). The Paleozoic basin fill recorded the transition from a passive to a 
convergent margin, and the strata are characterized by pre-orogenic and syn-orogenic units (Babaei and Viele, 1992). The estimated basin size is $550 \mathrm{~km}$ long and $450 \mathrm{~km}$ wide at the beginning of Carboniferous (Coleman, 2000). The paleolatitude of the Ouachita Basin during the Carboniferous was $15^{\circ}-0^{\circ} \mathrm{S}$ (Coleman, 2000). The basin was shortened by $\sim 50 \%$ due to south-north subduction during this period (Coleman, 2000). The preorogenic Cambrian-Middle Mississippian strata represent a period of sediment starvation (Morris, 1974b). The dominant basin fill is deep marine shale, turbidite sandstone, and chert, with a maximum thickness of $\sim 4000 \mathrm{~m}$ and an average sedimentation rate of 30m/Myr (Morris, 1974b). The syn-orogenic strata are the Mississippian Stanley Group, the Lower Pennsylvanian Jackfork Group, Johns Valley Formation, and the LowerMiddle Pennsylvanian Atoka Formation (Fig. 2C). The dominant lithologies are deep marine turbidite sandstones and shales, with a maximum thickness of over $10000 \mathrm{~m}$, and an average sedimentation rate of $\sim 300 \mathrm{~m} / \mathrm{Myr}$ (Morris, 1974b). The deposition of the synorogenic strata was coeval with relative sea level low, high precipitation rate, and intense tectonic activity (Fig. 2C, Coleman, 2000). During the Atokan Epoch (Fig. 2C), the southern Laurentian margin experienced the greatest subsidence and finally transitioned from the Ouachita remnant ocean basin to the Arkoma Foreland Basin (Houseknecht, 1986; Arbenz, 2008). The basin fill shoals upward from turbidites to shallow marinefluvial deposits (Houseknecht, 1986). The crest of the accretionary wedge (the Ouachita Mountains) became uplifted and was subject to subaerial erosion towards the end of Atokan (Arbenz, 2008). The structural map of the Ouachita Mountains has been divided into several zones by different deformational styles (Stone and Haley, 1984; Arbenz, 2008). The terminologies of structural zones in this study are adopted from the most 
recent tectonic reconstruction (Arbenz, 2008). They are defined as follows (Fig. 2): Foredeep (FD) - The Ouachita Frontal Zone, imbricated orogenic foredeep (Briggs, 1974; Houseknecht, 1986; Arbenz, 2008), between Ross Creek-Choctaw faults and Y City-Ti Valley faults. Wedge-top (WT) -The Main Ouachita Allochthon, highly deformed, south of the Y City-Ti Valley faults and extends to the subsurface. We focus on the quantitative comparison of the stratigraphy of the two depozones in this study. These two zones are further divided into east (FD-E and WT-E) and west (FD-W and WT-W) subzones by the Arkansas-Oklahoma state line respectively in order to reveal longitudinal variations.

\subsection{Depositional system of Lower Atoka Formation (LAF)}

The Atoka Formation recorded important stratigraphic and tectonic information of the remnant ocean-foreland basin transition. It is one of the most extensively outcropped stratigraphic units in the Ouachita Mountains with a maximum thickness over $8000 \mathrm{~m}$ in the foredeep (Morris, 1974a). The Atoka Formation is informally divided into three members: Lower, Middle, and Upper Atoka (Zachry and Sutherland, 1984; Haley et al., 1993). The Lower Atoka Formation (LAF), the focus of this study, is a fine-grained, sand-rich turbidite system and outcrops in FD and WT. The maximum thickness is $\sim 4500 \mathrm{~m}$ in FD and $\sim 1500 \mathrm{~m}$ in WT (Arbenz, 2008). The Middle and Upper Atoka formations are mud-rich, fine- to medium-grained shallow marine, and fluvial-deltaic deposits (Haley and Stone, 2006), and primarily outcrop in the Arkoma foreland basin and partially in FD. The LAF has been interpreted as a laterally-confined, multi-sourced turbidite system (Fig. 3), with the dominant source entering the basin from the east and the submarine fans building towards the west (Sprague, 1985; Houseknecht, 1986; 
Coleman, 2000). The basin confinement is inferred from regional lithofacies trends, paleocurrent directions, tectonic reconstructions, and paleogeography (Briggs and Cline, 1967; Morris, 1974b; Graham et al., 1975; Nelson et al., 1982; Lillie et al., 1983; Sprague, 1985; Viele and Thomas, 1989) but the spatial variation of basin confinement has not been investigated. The contrast of the LAF in FD and WT (Walthall, 1967; Sprague, 1985) has not been quantitatively described. Geophysical surveys (Nelson et al., 1982; Lillie et al., 1983; Mickus and Keller, 1992; Keller and Hatcher, 1999) and more recent tectonic reconstructions in the Ouachita Mountains (Arbenz, 2008; Johnson, 2011; Thomas, 2011) show drastic contrasts between the FD and WT during the Atokan (Fig. 2D). The structure and topography in FD are relatively simple and smooth, while those in WT are highly corrugated due to folds and syn-depositional thrust faults. This difference implies contrasting degrees of confinement in the two depozones due to inherited topography and syn-depositional tectonics.

\section{Data and Methodology}

\subsection{Data collection}

Our dataset consists of 43 measured sections throughout the study area (Fig. 2A, Table SDT 1). The accumulated measured thickness is $\sim 2020 \mathrm{~m}$, and the number of bed thickness measurements is $\sim 9500$. These sections captured the changes in lithology, thickness, sedimentary structures, grain-size, and the nature of contacts at $2 \mathrm{~cm}$ resolution (Table SDT 2). A total of 247 paleocurrent directions from flute casts were measured to 
confirm previous interpretations of sediment dispersal patterns (Sprague, 1985; Houseknecht, 1986; Coleman, 2000). Photo mosaics were taken to assist facies architecture interpretations. Our dataset incorporated previous measured sections (Sprague, 1985) in the following localities due to vegetation and limited accessibility in the present day: 28, 30, 34, 37, 38, 39, 41, 42, and 43 (Fig. 2A).

While non-amalgamated sandstones are relatively simple to identify, amalgamated sandstones were separated into individual sandstone beds where possible, but we acknowledge the difficulty in recognizing amalgamated beds and the potential effects in bed thickness comparisons (Sinclair and Cowie, 2003; Sylvester, 2007). The amalgamation surfaces can be identified by subtle grain size changes, differential weathering on either side of the surfaces, and sometimes the presence of thin and discontinuous mudstone films along the surfaces. The amalgamation ratio of a stratigraphic interval is defined here as the number of amalgamated surfaces divided by the total number of beds (Romans et al., 2009). The percent sandstone (or 'net-to-gross') of a stratigraphic interval is expressed as the ratio of the total sandstone thickness over the total thickness of this interval. Hybrid beds (Haughton et al., 2003, 2009) and chaotically bedded deposits are volumetrically insignificant $(\sim 5 \%)$ and excluded in the subsequent statistical comparisons. No attempt has been made to separate turbidite mudstones and hemipelagic mudstones, because a) the primary interest of this study is the sandstones and sand-rich units, and b) true hemipelagic mudstones are rare in the outcrops and most of them are poorly weathered and vegetated and difficult to measure accurately. There is no need to correct the thicknesses by paleocurrent directions because 
the outcrops strike nearly perpendicular to the mean paleocurrent directions and the variations of paleocurrent directions are relatively low (Fig. 4).

Basin-wide correlations of the measured sections are difficult due to lack of exposure, structural complexity, and lack of datum (Fulton, 1985; Sprague, 1985; LaGrange, 2002). In order to reveal the basin-wide longitudinal and lateral variations, we compiled the data within the FD and WT depozones and the subzones (FD-E, FD-W, WT-E, and WT-W) to make broad comparisons. Apparently, the outcrops are not distributed evenly in each depozone and subzone (Fig. 2A) but they tend to follow the structural strikes and the mean sediment transport directions (Figs. 3 and 4). Herein, we assume the bulk statistics from each depozone and subzone is a time- and space-averaged dataset. We acknowledge the potential biases and error associated with this assumption and therefore presented the confidence levels of the thickness distributions (Figs. 9, 10, 11, 12, and 13) and the standard errors for the compiled datasets.

\subsection{Definitions of facies hierarchy}

\subsubsection{Lithofacies scheme}

Several lithofacies schemes of the LAF have been developed previously in the FD depozone in Arkansas (Fulton, 1985; LaGrange, 2002) and for the both FD and WT depozones in Arkansas and Oklahoma (Sprague, 1985). The lithofacies schemes developed for the more well-known Jackfork Group (Al-siyabi, 2000; Morris, 1974b; Slatt et al., 2000; Zou et al., 2012) in the study area are highly applicable to the Pennsylvanian turbidites in the Ouachita Mountains. For this study, we developed a 
scheme of 5 lithofacies (Fig. 5, Table 1) with reference to the previous work of the LAF and Jackfork Group mentioned above, denoted as F1 to F5 respectively.

\subsubsection{Hierarchy scheme}

Hierarchical approaches are useful to characterize and compare turbidite systems at different scales (Hubbard et al., 2008; Prélat et al., 2009; Romans et al., 2011). Few outcrops allow recognition of facies architectures with strict geometric criteria, and therefore a hierarchy scheme objectively built upon bounding surfaces, facies information, and supported by geometries is especially useful (Hubbard et al., 2008; Prélat et al., 2009).

The LAF has been interpreted as a 'middle fan' environment (Fulton, 1985; Sprague, 1985; LaGrange, 2002) which covers a variety of subenvironments. An effective facies hierarchy scheme for this study should a) distinguish the variations of subenvironments, b) have enough scales to show a hierarchical trend, and c) be 'lightweight' enough for statistical comparison and data visualization. We employed a 3-scale hierarchical scheme in this study (Fig. 6). The building block is the 'bed' (B), which represents the deposit of a single turbidity event (Mutti and Normark, 1987; Pickering and Hiscott, 2016). We then divided the LAF into 4 broad architectural elements (E): channel element (E1), lobe element (E2), mudstone sheet (E3), and slump (E4) (Prather et al., 2000; Pyles et al., 2008). Likewise, these architectural elements stack to form the stratigraphic architectures (A): channel (A1), lobe (A2), interchannel-interlobe (A3), and mass transport deposit (A4). The definitions are given in Table 1. 


\subsection{Data processing and visualization}

For each measured section, we interpreted the facies hierarchies and calculated the thickness of each hierarchical scale. The relative abundance is defined by the percentages of the total thickness of each type of facies hierarchy within a zone. The relative frequency of occurrence for each type of facies hierarchy is the frequency of occurrences normalized by the number of occurrences of all facies hierarchies within a zone. The purpose of using relative parameters is to correct sample size biases.

We used 3 hierarchical thickness datasets for comparative analyses: lobe sandstone bed (B), lobe element (E2), and lobe (A2) for each zone. We used 3 graphical demonstrations to show the statistical distributions: empirical exceedance cumulative distribution function (also exceedance probability or survivor function), kernel density estimation, and boxplots (Figs. 9, 10, 11, 12, and 13). The exceedance probability emphasizes the thicker tail of the distribution and is thus preferred comparing to a regular empirical cumulative distribution function. The heavier thick-bedded tail is interpreted to be an indicator of stronger topographic confinement (Marini et al., 2016a). The exceedance probability plots are accompanied with upper and lower bounds of the $90 \%$ confidence level range. The kernel density estimations are all calculated with a bandwidth of $0.2 \mathrm{~m}$ and a number of points of 500. The boxplots are calculated with the whisker length equals the interquartile range. The descriptive statistics are presented in Table 2 to assist interpretation. To quantify and visualize the statistical differences between the depozones and between the east and west, we utilized the one-sided two-sample KolmogorovSmirnov (K-S) test and quantile-quantile (Q-Q) plots. The one-sided K-S test was used because we are more interested to know which distribution is larger, rather than whether 
the two distributions are equal. The significance level (alpha) is set to be 0.1 , which indicates a $10 \%$ chance of type I error. Digitization, calculation, and data visualization were performed in Matlab®.

\section{Results}

The results of this study are presented by spatial trends and hierarchical scales. Spatially, we first present the longitudinal (east-west or proximal-distal) variations of facies hierarchies and thickness distribution in the foredeep (FD) and wedge-top (WT). Then we present the lateral (north-south) variations between FD and WT in the east and the west respectively. Hierarchically, we first compare the proportions and frequencies of lithofacies, architectural elements (E), and stratigraphic architectures (A) of each zone. Then we compare the thickness distributions of each zone at 3 hierarchical scales: lobe sandstone bed (B), lobe element (E2), and lobe (A2).

\subsection{Abundance and frequency of facies hierarchy}

FD is represented by an accumulated thickness of $1502 \mathrm{~m}$. The mean percent sandstone and amalgamation ratio is $54 \%$ and $33 \%$ respectively. F1 is the most common sand-rich lithofacies by the thickness (Fig. 7), whereas F3 is most common by frequency (Fig. 8). FD is a lobe-dominated system, with a degree of channelization of 8-9\% by the thickness (Fig. 7) or 3-4\% by frequency (Fig. 8). WT is represented by an accumulated thickness of $449 \mathrm{~m}$. The mean percent sandstone and amalgamation ratio is $73 \%$ and $32 \%$ respectively. Similarly, the F1 is the most common sand-rich lithofacies by the thickness 
(Fig. 7), but F3 is most common by frequency (Fig. 8). It is also a lobe-dominated system, the degree of channelization of which is $14 \%$ by the thickness (Fig. 7) or $8 \%$ by frequency (Fig. 8).

\subsubsection{Longitudinal variations}

The FD exhibits significant longitudinal variations in facies hierarchies. The FD-E is represented by an accumulated $1020 \mathrm{~m}$ of measured sections, while the FD-W by $482 \mathrm{~m}$ of measured sections. From FD-E to FD-W, the percent sandstone and amalgamation ratio decrease from $64 \%$ to $31 \%$ and from $40 \%$ to $20 \%$, respectively. There is a significant decrease of sand-rich lithofacies and an increase of mud-rich lithofacies from FD-E to FD-W by both abundance and frequency (Figs. 7 and 8 ). Similar trends persist to the E and A hierarchical scales by abundance (Fig. 7) but not by frequency (Fig. 8). There are subtle variations between FD-E and FD-W at E and A hierarchical scales by frequency, except for the decrease in channelization and mass failure (Fig. 8). Conversely, the WT exhibits little longitudinal variations in facies hierarchies. The WT-E is represented by an accumulated $366 \mathrm{~m}$ of measured sections, while the WT-W by $82 \mathrm{~m}$. From WT-E to WT-W, the percent sandstone and amalgamation ratio decrease from $75 \%$ to $66 \%$ and from $33 \%$ to $28 \%$, respectively. There is a subtle increase in sand-rich lithofacies and an increase of mud-rich lithofacies from WT-E to WT-W by both abundance and frequency (Figs. 7 and 8). For E and A hierarchical scales, there is an increase of channelization at the cost of decreased lobe deposits by abundance (Fig. 7). Similar with FD, there are also little variations between WT-E and WT-W by the frequency at the scale of E (Fig. 8). However, at the scale of A, there is a decrease in channelization by frequency (Fig. 8). 
The deposits of mass failure events roughly remain low and constant longitudinally by both abundance and frequency (Figs. 7 and 8 ).

\subsubsection{Lateral variations}

In the east, the FD-E exhibits lower percent sandstone (64\% vs $75 \%$ ) and higher amalgamation ration (40\% vs 33\%) comparing to WT-E. In general, the two subzones show nearly identical proportions and frequencies at all hierarchical scales, except that the WT-E is slightly more sand-rich and more channelized by abundance but not necessarily by frequency (Figs. 7 and 8). In the west, the FD-E exhibits noticeably lower percent sandstone (31\% vs $66 \%$ ) and amalgamation ratio (20\% vs $28 \%$ ) comparing to WT-W. The sand-rich lithofacies in FD-W is less than half of that in WT-W by abundance (Fig. 7). Similar trends persist to the scales of E and A, which shows a significant decrease in lobe deposits and channelization by abundance from WT-W to FD-W (Fig. 7). The FD-W also exhibits considerably lower F1 and F2 and higher F3 comparing to WT-W by frequency (Fig. 8). However, for the scales of E and A, FD-W only exhibits slightly fewer lobe deposits and lower channelization by frequency, comparing to WT-W (Fig. 8).

In summary, there is a significant longitudinal decrease in percent sandstone, amalgamation ratio, and abundance of sand-rich facies hierarchies in the FD, in contrast to subtle longitudinal variations in WT measured by the same parameters. Meanwhile, there are only subtle longitudinal variations in the frequency of facies hierarchies in both zones. The FD and WT are similar in the east by both abundance and frequency, but different in the west with the FD-W being more mud-rich by abundance. 


\subsection{Thickness distribution}

The FD dataset consists of the thicknesses of 2616 lobe sandstone beds (B), 491 lobe elements (E2), and 310 lobes (A2), the ranges of which are $0.02-3 \mathrm{~m}, 0.2-13 \mathrm{~m}$, and 0.3 20m, respectively. The WT dataset consists of 995 beds, 194 E2, and 76 A2, the ranges of which are $0.02-2.5 \mathrm{~m}, 0.2-14 \mathrm{~m}$, and $0.3-18 \mathrm{~m}$, respectively. The descriptive statistics are listed in Table 2. The hierarchical variations of the thickness distributions are demonstrated by Q-Q plots (Fig. 14). All comparative results of the statistical distributions are validated with K-S tests, the result of which are listed in Table 3.

\subsubsection{Longitudinal variation}

The thickness distributions in FD displays significant longitudinal decrease at all 3 scales of hierarchies (Fig. 9). All the exceedance probability plots (ECDFs) in FD-E exhibit more convex and right-shifted shapes comparing to those of the FD-W. The ECDFs of FD-E separate from those of the FD-W at less than $0.1 \mathrm{~m}$ at the bed scale, $\sim 0.2 \mathrm{~m}$ at the E scale, and $\sim 0.3 \mathrm{~m}$ at the A scale. The gaps between FD-E and FD-W are well beyond their $90 \%$ confidence bounds. The kernel density estimations (KDE) of FD-E are more positively skewed and more peaked comparing to those of the FD-W at all 3 hierarchical scales. The box plots of FD-E show greater thickness dispersions and higher median values than those of the FD-W, while both subzones show a considerable amount of outliers.

In contrast, the thickness distributions in WT displays only subtle longitudinal trends at all 3 scales of hierarchies (Fig. 10). At bed scale, the ECDFs in WT-E and WT-W exhibit 
identical shapes and cannot be distinguished with $90 \%$ confidence bounds. However, WT-E exhibits an increasing amount of thick populations with increasing hierarchy comparing to those of the WT-W, and the gaps between the WT-E and WT-W become wider. The KDE of the WT-E appears to be more positively skewed and peaked than WT-W for E2, but it becomes equally skewed and less peaked comparing to WT-W for A2. The box plots of WT-E show smaller thickness dispersion and similar median values with that of the WT-W for bed. It shows greater thickness dispersion and lower median values than WT-W for E2, and greater thickness dispersion and considerably higher median values than WT-W for A2.

\subsubsection{Lateral variation}

There are subtle differences between FD-E and WT-E in the eastern part of the study area for bed datasets, but the difference appears to be greater with increasing hierarchies (Figs. 12 and 14). The ECDFs of FD-E and WT-E cannot be confidently distinguished below $0.5 \mathrm{~m}$ or above $5 \%$ probability for bed datasets. The ECDF of FD-E is slightly greater than that of WT-E for E2 when the thickness is below $\sim 4 \mathrm{~m}$ or $\sim 6 \%$, where they cross over each other. The trend is reversed afterward. The ECDF of WT-E is more convex and right-shifted than FD-E for A2, albeit that WT-E has a wider range of confidence bounds especially towards the end of the thick tail. Similar trends persist to the KDEs. The KDEs of FD-E and WT-E are identical for thickness greater than 0.1 at the bed scale. The KDE of FD-E appears less peaked and less positively skewed than WT-E at E2 scale. The KDE of FD-E transitions to equally skewed and more peaked than WT-E at A2 scale. The box plots of FD-E display slightly higher median values and similar dispersion with that of WT-E for bed dataset. The FD-E displays noticeably higher median value and similar 
dispersion with the WT-E for E2. For A2 dataset, the FD-E displays a lower median value and smaller dispersion than WT-E. In contrast, the differences between FD-W and WT-W are obvious in the western part of the study area for all hierarchies (Fig. 12). The ECDFs of FD-W are consistently less convex and appear left-shifted than those of the WT-W, which can be roughly separated by the confidence bounds. The same trend persists in the KDEs and box plots. The KDEs of FD-W are consistently more peaked and more positively-skewed than those of the WT-W. The box plots of FD-W display consistently lower median values and smaller thickness dispersions.

In summary, there is a significant longitudinal decrease in the thickness distributions in FD at lobe sandstone (B), lobe element (E2) and lobe (A2) hierarchical scales expressed in ECDF, KDE and box plots, in contrast to the much smaller longitudinal decrease in the WT. The thickness dispersions in both the FD and the WT decrease from east to west in general at all hierarchical scales. Laterally, there are subtle differences in thickness distributions between the FD and WT in the east at all hierarchical scales, whereas in the west the thickness distributions of the FD are consistently smaller than those of the WT. In general, the WT exhibits greater thickness dispersions than the FD at all hierarchical scales in both the east and west.

\subsubsection{Hierarchical variation}

There are noticeable hierarchical variations mentioned in Sections 4.2.1 and 4.2.2. The statistical differences between each paired dataset appear to increase with hierarchy. The Q-Q plots (Fig. 14) of the paired datasets are more insightful to show the difference between the distributions and the hierarchical variations. Herein, we are concerned with the hierarchical trends of the Q-Q plots expressed by 3 aspects: the straightness, the 
relative position of the fitted line and the diagonal, and the changes in the slope of the fitted line.

Longitudinally in the FD, the quantiles of the FD-E and FD-W follow fairly straight lines at all 3 scales of hierarchies, which corresponds to their similar shapes in ECDFs. The quantiles of FD-E are consistently larger than those of FD-W and the data points fall below the diagonal, which corresponds to the greater thickness of FD-E. The slopes of the fitted lines appear to decrease slightly with increasing hierarchies, which corresponds to the increasing gaps between FD-E and FD-W distributions. Longitudinally in the WT, the quantiles of the data points tend to follow the diagonal for bed datasets, which suggests that the two are likely from the same population. However, the straightness decreases for E2 and A2 datasets, which suggests the difference between WT-E and WTW increases with hierarchy. The data points tend to fall below the diagonal at the thicktail but above it at the thin-tail for E2 and A2 datasets. The slopes of the fitted lines also tend to decrease with increasing hierarchies. Laterally in the eastern part of the study area, the quantiles of the FD-E and WT-E follow fairly straight lines at all hierarchies. The data points tend to follow the diagonal at the bed and E2 scales, but shift upward at the A2 scale, which suggests more thickening of lobe deposits in the WT with increasing hierarchy. The slopes of the fitted lines are consistent. Laterally in the western part, the quantiles of the FD-W and WT-W tend to swing around the fitted lines for all hierarchies, resulting in lower degrees of straightness. The quantiles of WT-W are consistently higher than those of FD-W and the data points fall above the diagonals. The slopes of the fitted lines tend to decrease with increasing hierarchy, which shows a decreasing thickness contrast with increasing hierarchy. 


\section{Discussion}

\subsection{Potential bias and limitations}

\subsubsection{Bed type selection}

For turbidite bed thickness analysis, it is advantageous to use event bed which equals a sedimentation unit (Talling, 2002; Sylvester, 2007). This approach has two requirements: a) confident recognition of turbidite mudstone and hemipelagic mudstone, and b) exclusion amalgamated sandstone beds. The first criterion can be difficult to satisfy due to outcrop exposure and weathering. The amalgamated sandstones are sometimes abundant and the exclusion will reduce the sample size considerably, especially the thickbedded population. Additionally, amalgamated beds are often the remnant of erosive and large turbidity events, the mud cap thickness (if ever deposited) of which cannot be measured from the stratigraphy. The alternative approach has been using the thickness of coarse-divisions of event beds (Fig. 6), which is more pragmatic for outcrop data collection and has proven useful in interpreting turbidite subenvironments and topographic confinement (Carlson and Grotzinger, 2001; Bersezio et al., 2005; Felletti and Bersezio, 2010; Marini et al., 2016a). We compared the two approaches using the dataset of LAF lobe deposits (Fig. 15). The thicknesses in FD-E are consistently greater than those of WT-E for sandstone, mudstone, and event bed datasets. The event bed dataset displays the same trend in the sandstone dataset but with greater contrast. This is due to their contrast in mudstone thickness distributions. The mudstone thickness 
distribution is probably modified by additional mud source from the north (Section 5.2). Using event bed thickness will add such uncertainties to the dataset and might affect the comparative results. Therefore, we favor the alternative approach that uses the thicknesses of sandstone beds as it is more applicable to our dataset.

\subsubsection{Thickness distributions of channel deposits}

Lobe deposits are common and aerially extensive in turbidite systems. Their thickness distribution is believed to be sensitive to topographic confinement (Tökés and Patacci, 2018). Lobe bed thickness has been widely used to infer or characterize basin confinement (Marini et al., 2015; Liu et al., 2018; Pantopoulos et al., 2018). Meanwhile, channel deposits are less aerially extensive but also display variable degrees of confinement (Campion et al., 2000; Bernhardt et al., 2011; Moody et al., 2012). The degree of confinement inferred from channel and lobe deposits combined are likely to be informative. We analyzed the thickness distributions hierarchically of FD-E and WT-E where the degree of channelization is high (Fig. 16, Table 4). The thickness of WT-E and FD-E channelized deposits are very similar to each other, and the datasets all exhibit fairly wide confidence levels (Fig. 16) and large standard errors (Table 4). The thickness distributions cannot be distinguished with one-sided K-S tests (Table 4). While this may be a function of the architecture and evolution of submarine channels comparing to lobes, the channelized deposit sample size is small and thus we exclude it from our analysis.

\subsubsection{Sampling bias}

Outcrop localities in this study show a broad temporal and spatial distribution, varying slightly in age and location within the depositional system. While this semi-random 
sampling is advantageous for statistical analysis and is useful for small sample sizes (Tversky and Kahneman, 1971), the smaller sample size and discrepancy and data coverage in WT do result in higher standard errors (Table 3). There may also be additional bias introduced by time-averaging the measured sections to represent the full Lower Atoka Formation (LAF) due to contrast in preservation in the foredeep (FD) and wedge-top (WT). The LAF transitions into Middle and Upper Atoka formations in the FD, then overlain by Hartshorne Formation (fluvial). In WT, the LAF is the youngest stratigraphic unit preserved and the true thickness is unknown (Arbenz, 2008). The maximum thickness of the LAF in FD is $\sim 4500 \mathrm{~m}$, approximately 3 times of the $\sim 1500 \mathrm{~m}$ in WT (Arbenz, 2008). As a result, it is possible that the LAF in WT represents only the basal portion, and the basal portion of confined (or ponded) basins are likely to be more confined than the upper portions (Pyles, 2008; Felletti and Bersezio, 2010; Gordon, 2014; Marini et al., 2015). With current data and the lack of a high-resolution, basin-wide chronostratigraphy, these limitations cannot be realistically resolved by statistical methods (e.g. Bootstrap resampling). We acknowledge the limitations of the dataset and advise caution for their applicability.

\subsection{Possible causes of the FD-WT contrast}

The FD and WT have shown clear contrast in terms of facies hierarchies and their thickness distributions. The main reasons for this contrast include sampling bias (discussed above), sediment supply, and topographic confinement.

\subsubsection{Sediment supply}


The LAF has been interpreted as a multi-sourced turbidite system (Houseknecht, 1986; Thomas, 1997; Coleman, 2000), but there are on-going debates on the sediment provenance (Gleason et al., 1994). There is a general agreement that the eastern source is dominant, but there is also potential sediment flux from the north (Laurentian craton) feeding the FD and from the south (Gondwana terranes) feeding the WT. The direct evidence of north-derived slope fan system of LAF is based on a single outcrop (the Blue Mountain Dam in Arkansas, Houseknecht et al., 2010). Slope fan systems are also found in Middle Atoka Formation, e.g. the Red Oak sandstone in Oklahoma (Xu et al., 2009). The presence of prevalent fluvial-deltaic systems along the northern Arkoma Shelf (Zachry, 1979; Jones and Zachry, 1994) are likely to feed these slope fan systems and eventually contribute to the foredeep fan. However, the slope fan systems do not seem to have a significant sand contribution to the FD, because detrital zircons from the eastern and western side of FD are very similar (Sharrah, 2006). Currently, there is a lack of direct evidence for the possible Gondwana source for WT. There is a small portion of outcrops in WT that show south-derived paleocurrent directions (Fig. 4), which do not show compositional differences from the east-derived sediments (Sprague, 1985). The presence of a Gondwana source for WT is largely postulated from a) the regional tectonic framework (Thomas, 1997), and b) the evidence of continental arc to the south of the Ouachita Basin in the older Jackfork Group (Zou et al., 2017) and Stanley Group (Shaulis et al., 2012). The nearly identical facies hierarchy portions and relative frequencies in FD-E and WT-E (Figs. 7 and 8) suggest they share a common source, although not necessarily from the sediment entry point (e.g. submarine canyon). The presence of slope fan systems in the Arkoma Basin and the postulated Gondwana source to the north do not 
seem to modify the bulk statistics of FD-E and WT-E. In other words, the sources other than the eastern one had limited sand contribution to the Ouachita Basin during the deposition of LAF. However, FD exhibits noticeably higher mud content and thicker mudstone distributions than WT (Fig. 15). This is most likely due to the mud deposited on the Arkoma shelf and slope (Houseknecht, 1986), which can be resuspended and deposited by storms or flooding events. Different volumes entering FD and WT can potentially result in different thickness distributions (sensu Sinclair and Tomasso, 2002). We would expect different thickness distributions for all hierarchical scales if this is the case. However, the thickness distributions in FD-E and WT-E are almost identical for bed dataset and very similar for lobe elements (Fig. 15). As discussed above, the Ouachita Basin is predominantly sourced from the east with some mud contribution from the north during the deposition of LAF. The sediment supply is not likely to be a dominant control on the disparity in facies hierarchy and thickness distributions between FD and WT.

\subsubsection{Topographic confinement}

The contrast of structural and topographic confinement between FD and WT is illustrated in the tectonic reconstruction (Fig. 2D, Arbenz, 2008; Suneson, 2008). The characteristics of the depozones in foreland basin systems are well-known (Mutti et al., 2003; Covault and Graham, 2008; DeCelles, 2012). Foredeep fans are not necessarily structurally confined (e.g. Tanqua-Karoo Basin, Nilsen et al., 2007), although some type of confinement is common (Lomas and Joseph, 2004). Likewise, wedge-top fans are commonly confined, but also show various degrees of confinement (Felletti and Bersezio, 2010; Bernhardt et al., 2012; Gordon, 2014). The contrast of structural setting between FD and WT is analogous to that of the wedge-top and foredeep in the Magallanes 
foreland basin (Bernhardt et al., 2011), the Tertiary Molasse foreland basin in Austria (Covault et al., 2009), and the Markran accretionary prism (Bourget et al., 2010). Topographic confinement and basin compartmentalization in the Ouachita Basin is most likely due to structural-induced topographic highs such as submarine ridge and scarp systems (Fig. 17, Gordon and Stone, 1977). Therefore, we interpret that the different degrees of lateral confinement is most likely to be the dominant control on the FD-WT contrast in facies hierarchy and thickness distributions.

\subsection{New understanding of LAF depositional system}

Almost all previous depositional models of the LAF are based on the FD dataset only (except Sprague, 1985), and there has been no quantitative data showing the trends of facies, facies hierarchies, or thickness distributions across the basin. We have characterized the longitudinal and lateral facies trends in the FD and WT respectively and compared their thickness distributions. The greatest difference between FD and WT is the contrast of longitudinal variations in both facies hierarchy and thickness distributions. The FD displays significant longitudinal decreases in amalgamation ratio, sand-rich facies hierarchies, and thickness distribution at all hierarchical scales. These decreases are most likely due to flow expansion, reduction in flow velocity and shear stress, reduction in sediment concentration and flow density of the turbidity currents (sensu Sinclair and Tomasso, 2002). The characteristics of the FD are best explained by proximal-distal facies trends of classical turbidite facies models (Walker, 1978; Bouma et al., 1985; Mutti, 1985; Mutti and Normark, 1987). The longitudinal variation of lobe deposits in FD is also analogous to proximal-distal or axial-marginal facies trend in the 
Tanqua-Karoo Basin (Spychala et al., 2017) but at a larger scale. In contrast, the WT displays little to no longitudinal variation in percent sandstone, amalgamation ratio, facies trend, and thickness distributions. The topographic confinement is most likely responsible for maintaining the flow velocity and shear stress, increasing flow height and inhibiting the flow expansion for much longer distance (sensu Sinclair and Cowie, 2003) comparing to FD. As a result, the sands have a higher probability to be delivered further into the basin. The lateral confinement of the WT is also likely responsible for the lower mudstone content in WT. The reason is that lateral confinement can increase flow efficiency and allow the upper half low density turbidity current to bypass much further, resulting in a higher probability of preserving lower coarse divisions in the stratigraphy. Therefore, we proposed a conceptual depositional model of the LAF system (Fig. 17), which shows two parallel turbidite systems: a foredeep system that is less confined where the traditional proximal-to-distal submarine-fan facies model applies, and a wedge-top system that is more topographically complex and confined, causing a disruption to the proximal-to-distal evolution of flows.

\subsection{Implications of thickness distribution as a proxy for basin confinement}

Firstly, our results show that proximity and topographic confinement can impose similar signatures on the bulk statistics of the thickness of turbidite deposits at multiple scales. This suggests that first using bulk statistics of turbidite thickness to infer topographic confinement can be problematic without addressing the facies trends and sampling locations (Malinverno, 1997; Sylvester, 2007; Marini et al., 2016a). Additionally, each basin operates under a set of external forces (Bouma, 2000) which all have their own 
frequencies and amplitudes (Romans et al., 2016). These factors require careful investigation. Secondly, the bed thickness datasets of entire FD and WT show very similar distributions and are statistically indistinguishable, but they show different longitudinal trends after binning into eastern and western data sets. This phenomenon resembles the Simpson's Paradox in statistical studies (Blyth, 1972), which states the statistical trends in different groups may disappear when these data are combined into one. Therefore, it is important to carefully choose datasets and subsets to analyze thickness distributions. Thirdly, the contrast of thickness distributions between FD and WT subzones increase with hierarchy. At the bed scale, it is difficult to separate the FD and WT distributions without breaking them into subsets by proximity. At the lobe scale, the contrast between FD and WT is more obvious. This phenomenon likely suggests that turbidite systems respond to basin confinement in a hierarchical manner. The degree of confinement is dependent on the flow size relative to the accommodation size (Ja'Aidi et al., 2004). Therefore, the stratigraphic contrast of confined turbidite systems and unconfinement systems are transitional without a clear-cut boundary. At the bed scale in turbidite lobe systems, the turbidity currents are probably not sensitive to topographic barriers because they cannot always expand and cover the whole accommodation area. As beds stack to form lobe elements and lobe elements to lobes, the signal of confinement is magnified through the hierarchy (sensu Straub et al., 2009). The likely reason is that hierarchical stacking of compensation increases with hierarchical scales (Straub and Pyles, 2012). For the LAF dataset, each lobe (A2) in the entire FD is composed of 8.4 sandstone beds on average, comparing to 13.1 in WT (Table 3). Similarly, for the proximal locations, each lobe in FD-E is composed of 9.8 sandstone 
beds on average, comparing to 15.3 in WT-E. The results correspond to the proximaldistal increase of compensational stacking (Straub and Pyles, 2012). The higher average bed numbers in lobes in WT suggest anti-compensational stacking (Straub et al., 2009) in more confined settings. The subtle discrepancy in confinement signals is thus multiplied from bed to lobe scales.

\section{Conclusion}

To understand the influence of lateral confinement on submarine fan deposits, we compared the longitudinal and lateral trends of facies hierarchies and thickness distributions of turbidite lobe sandstone beds, lobe elements, and lobe architectures of the foredeep and the wedge-top depozones of the Lower Atoka Formation in the Ouachita Basin. Both depozones are predominantly sourced from the east and the greatest difference is the degree of structural and topographic confinement. The seafloor topography in the foredeep is relatively smooth and the wedge-top is characterized by elongated submarine ridges and valleys. The foredeep displays classical proximal-distal facies variations of submarine fan systems in both facies and thickness datasets. In contrast, the wedge-top depozone exhibits little to no proximal-distal facies variability and thickness distributions, indicating a higher degree of lateral confinement. Since proximity and confinement can impose similar signatures in thickness distributions, it is recommended to always combine facies analysis with thickness analysis. Dividing the thickness datasets into subsets spatially can reveal important signatures of proximity and confinement, which is otherwise masked by dataset amalgamation. The difference 
between the Ouachita foredeep and wedge-top thickness distributions increase from bed to lobe scales, indicating a hierarchical magnification of confinement signatures.

\section{Acknowledgment}

This paper is part of the first author's Ph.D. work funded by the Chevron Center of

Research Excellence at the Colorado School of Mines. We thank Hang Deng and Jingqi Xu for field assistance, and Cathy Van Tassel and Debora Cockburn for logistic support. 


\section{References}

Al-Siyabi, H.A., 2000, Anatomy of a Type II Turbidite Depositional System: Upper Jackfork Group, DeGray Lake Area, Arkansas, in Bouma, A.H. and Stone, C.G. eds., Fine-Grained Turbidite Systems, AAPG Memoir 72 / SEPM Special Publication 68, Tulsa, Oklahoma, Oklahoma, AAPG, p. 245-261.

Arbenz, J.K., 2008, Structural framework of the Ouachita Mountains, in Suneson, N.H. ed., Stratigraphic and Structural Evolution of the Ouachita Mountains and Arkoma Basin, Southeastern Oklahoma and West-Central Arkansas: Applications to Petroleum Exploration 2004 Field Symposium (The Arbenz-Misch/Oles Volume), Norman, Oklahoma, Oklahoma Geological Survey, p. 1-42.

Babaei, A., and Viele, G.W., 1992, Two-decked nature of the Ouachita Mountains, Arkansas: Geology, v. 20, p. 995-998, doi:10.1130/00917613(1992)020<0995:TDNOTO>2.3.CO;2.

Bernhardt, A., Jobe, Z.R., and Lowe, D.R., 2011, Stratigraphic evolution of a submarine channel-lobe complex system in a narrow fairway within the Magallanes foreland basin, Cerro Toro Formation, southern Chile: Marine and Petroleum Geology, v. 28, p. 785-806, doi:10.1016/j.marpetgeo.2010.05.013.

Bernhardt, A., Stright, L., and Lowe, D.R., 2012, Channelized debris-flow deposits and their impact on turbidity currents: The Puchkirchen axial channel belt in the Austrian Molasse Basin: Sedimentology, v. 59, p. 2042-2070, doi:10.1111/j.1365-3091.2012.01334.x.

Bersezio, R., Felletti, F., and Micucci, L., 2005, Statistical analysis of stratal patterns and facies changes at the terminations of "turbiditic" sandstone bodies: The Oligocene Cengio Unit (Tertiary Piedmont Basin): GeoActa, v. 4, p. 83-104.

Blyth, C.R., 1972, On Simpson's paradox and the sure-thing principle: Journal of the American Statistical Association, v. 67, p. 364-36, doi:10.1080/01621459.1972.10482387.

Booth, J.R., Dean, M.C., DuVernay, A.E., and Styzen, M.J., 2003, Paleo-bathymetric controls on the stratigraphic architecture and reservoir development of confined fans in the Auger Basin: central Gulf of Mexico slope: Marine and Petroleum Geology, v. 20, p. 563-586, doi:10.1016/j.marpetgeo.2003.03.008.

Bouma, A.H., 2000, Coarse-grained and fine-grained turbidite systems as end-member models: applicability and dangers: Marine and Petroleum Geology, v. 17, p. 137143, doi:10.1016/s0264-8172(99)00020-3.

Bouma, A.H., 1962, Sedimentology of some Flysch deposits: a graphic approach to facies interpretation: Amsterdam; New York, Elsevier Pub. Co., 168 p.

Bouma, A.H., Normark, W.R., and Barnes, N., 1985, Submarine Fans and Related Turbidite Systems (A. H. Bouma, W. R. Normark, \& N. Barnes, Eds.): New York; Berlin; Heidelberg; Tokyo, Springer-Verlag, 351 p. 
Bourget, J., Zaragosi, S., Mulder, T., Schneider, J.L., Garlan, T., Van Toer, A., Mas, V., and Ellouz-Zimmermann, N., 2010, Hyperpycnal-fed turbidite lobe architecture and recent sedimentary processes: A case study from the Al Batha turbidite system, Oman margin: Sedimentary Geology, v. 229, p. 144-159, doi:10.1016/j.sedgeo.2009.03.009.

Briggs, G., 1974, Carboniferous Depositional Environments in the Ouachita MountainsArkoma Basin Area of Southeastern Oklahoma: Geological Society of America Special Paper, v. 148, p. 225-239, doi:10.1130/SPE148-p225.

Briggs, G., and Cline, L.M., 1967, Paleocurrents and source areas of Late Paleozoic sediments of the Ouachita Mountains, southeastern Oklahoma: Journal of Sedimentary Petrology, v. 37, p. 985-1000, doi:10.1306/74D7180C-2B21-11D78648000102C1865D.

Campion, K.M., Sprague, A.R., Mohrig, D., Lovell, R.W., Drzewiecki, P.A., Sullivan, M.D., Ardill, J.A., Jensen, G.N., and Sickafoose, D.K., 2000, Outcrop Expression of Confined Channel Complexes, in Deep-Water Reservoirs of the World: 20th Annual, SOCIETY OF ECONOMIC PALEONTOLOGISTS AND MINERALOGISTS, v. 44, p. 127-150, doi:10.5724/gcs.00.15.0127.

Carlson, J., and Grotzinger, J.P., 2001, Submarine fan environment inferred from turbidite thickness distributions: Sedimentology, v. 48, p. 1331-1351, doi:10.1046/j.1365-3091.2001.00426.x.

Chakraborty, P.P., Mukhopadhyay, B., Pal, T., and Dutta, G.T., 2002, Statistical appraisal of bed thickness patterns in turbidite successions, Andaman Flysch Group, Andaman Island, India: Journal of Asian Earth Sciences, v. 21, p. 189-196, doi:10.1016/S1367-9120(02)00038-X.

Chen, C., and Hiscott, R.N., 1999a, Statistical analysis of facies clustering in submarinefan turbidite successions: Journal of Sedimentary Research, v. 69, p. 505-517, doi:10.2110/jsr.69.505.

Chen, C., and Hiscott, R.N., 1999b, Statistical analysis of turbidite cycles in submarine fan successions: tests for short-term persistence: Journal of Sedimentary Research, v. 69 , p. 486-504, doi:10.2110/jsr.69.486.

Clark, B.E., and Steel, R.J., 2006, Eocene Turbidite-Population Statistics from Shelf Edge to Basin Floor, Spitsbergen, Svalbard: Journal of Sedimentary Research, v. 76, p. 903-918, doi:10.2110/jsr.2006.078.

Coleman, J.L., 2000, Carboniferous submarine basin development of the Ouachita Mountains of Arkansas and Oklahoma, in Bouma, A.H. and Stone, C.G. eds., AAPG Memoir 72 / SEPM Special Publication No. 68: Fine-Grained Turbidite Systems, The American Association of Petroleum Geologists and SEPM (Society for Sedimentary Geology), p. 21-32.

Covault, J.A., and Graham, S.A., 2008, Turbidite Architecture in Proximal Foreland Basin System Deep-Water Depocenters: Insights from the Cenozoic of Western Europe: Austrian Journal of Earth Sciences, v. 101, p. 36-51. 
Covault, J.A., Hubbard, S.M., Graham, S.A., Hinsch, R., and Linzer, H.G., 2009, Turbidite-reservoir architecture in complex foredeep-margin and wedge-top depocenters, Tertiary Molasse foreland basin system, Austria: Marine and Petroleum Geology, v. 26, p. 379-396, doi:10.1016/j.marpetgeo.2008.03.002.

Covault, J.A., and Romans, B.W., 2009, Growth patterns of deep-sea fans revisited: Turbidite-system morphology in confined basins, examples from the California Borderland: Marine Geology, v. 265, p. 51-66, doi:10.1016/j.margeo.2009.06.016.

DeCelles, P.G., 2012, Foreland basin systems revisited: variation in response to tectonic settings, in Busby, C. and Azor, A. eds., Tectonics of Sedimentary Basins: Recent Advances, Chichester, UK, John Wiley \& Sons, Ltd, p. 405-427.

Deptuck, M.E., Piper, D.J.W., Savoye, B., and Gervais, A., 2008, Dimensions and architecture of late Pleistocene submarine lobes off the northern margin of East Corsica: Sedimentology, v. 55, p. 869-898, doi:10.1111/j.13653091.2007.00926.x.

Donald R. Lowe, 1982, Sediment Gravity Flows: II Depositional Models with Special Reference to the Deposits of High-Density Turbidity Currents: SEPM Journal of Sedimentary Research, v. Vol. 52, p. 279-297, doi:10.1306/212F7F31-2B2411D7-8648000102C1865D.

Felletti, F., 2002, Complex bedding geometries and facies associations of the turbiditic fill of a confined basin in a transpressive setting (Castagnola Fm, Tertiary Piedmont Basin, NW Italy): Sedimentology, v. 49, p. 645-667, doi:10.1046/j.1365-3091.2002.00467.x.

Felletti, F., and Bersezio, R., 2010, Quantification of the degree of confinement of a turbidite-filled basin: A statistical approach based on bed thickness distribution: Marine and Petroleum Geology, v. 27, p. 515-532, doi:10.1016/j.marpetgeo.2009.11.003.

Fryer, R., and Jobe, Z.R., 2018, Quantification of the Bed-scale Architecture of Submarine Depositional Environments and Application to Lobe Deposits of the Point Loma Formation, California: EarthArXiv, doi:10.31223/osf.io/dxyqg.

Fulton, D.A., 1985, Sedimentology, structure, and thermal maturity of the lower Atoka formation, Ouachita frontal thrust belt, Yell and Perry counties, Arkansas: University of Missouri - Columbia, $222 \mathrm{p}$.

Gawthorpe, R.L., and Leeder, M.R., 2000, Tectono-sedimentary evolution of active extensional basins: Basin Research, v. 12, p. 195-218, doi:10.1111/j.13652117.2000.00121.x.

Gleason, J.D., Patchett, P.J., Dickinson, W.R., and Ruiz, J., 1994, Nd isotopes link Ouachita turbidites to Appalachian sources: Geology, v. 22, p. 347-350, doi:10.1130/0091-7613(1994)022<0347:NILOTT>2.3.CO;2. 
Gordon, G.S., 2014, Stratigraphic Evolution and architectural analysis of structurally confined submarine fans: a tripartite outcrop-based study: Colorado School of Mines, $180 \mathrm{p}$.

Gordon, M., and Stone, C.G., 1977, Correlation of the Carboniferous Rocks of the Ouachita Trough with Those of the Adjacent Foreland, in Stone, C.G. ed., Symposium of the geology of the Ouachita Mountains Volume 1, Little Rock, Arkansas Geological Commission, p. 70-91.

Graham, S.A., Dickinson, W.R., and Ingersoll, R. V., 1975, Himalayan-Bengal Model for Flysch Dispersal in the Appalachian-Ouachita System: Geological Society of America Bulletin, v. 86, p. 273, doi:10.1130/00167606(1975)86<273:HMFFDI>2.0.CO;2.

Haley, B.R., Glick, E.E., Bush, W. V., Clardy, B.F., Stone, C.G., Woodward, M.B., and Zachry, D.L., 1993, Geologic Map of Arkansas 1:500 000 (N. F. Williams \& D. A. Peck, Eds.): Little Rock, Arkansas, U.S. Geological Survey \& Arkansas Geological Commission, 1 p.

Haley, B.R., and Stone, C.G., 2006, Geologic Map of the Ouachita Mountain Region and a Portion of the Arkansas River Valley Region in Arkansas 1:125000 (W. D. Hanson, Ed.): Little Rock, Arkansas, Arkansas Geological Commission, 1 p.

Haughton, P.D.W., Barker, S.P., and McCaffrey, W.D., 2003, "Linked" debrites in sandrich turbidite systems - Origin and significance: Sedimentology, v. 50, p. 459-482, doi:10.1046/j.1365-3091.2003.00560.x.

Haughton, P.D.W., Davis, C., McCaffrey, W.D., and Barker, S.P., 2009, Hybrid sediment gravity flow deposits - Classification, origin and significance: Marine and Petroleum Geology, v. 26, p. 1900-1918, doi:10.1016/j.marpetgeo.2009.02.012.

Heckel, P.H., and Clayton, G., 2006, The Carboniferous System. Use of the new official names for the subsystems, series and stages: Geologica Acta, v. 4, p. 403-407, doi:10.1016/S0016-7878(06)80045-3.

Houseknecht, D.W. et al., 2010, Assessment of undiscovered natural gas resources of the Arkoma Basin Province and geologically related areas: U.S. Geological Survey Fact Sheet 2010-3043, p. 1-4, doi:10.3133/fs20103043.

Houseknecht, D.W., 1986, Evolution from passive margin to foreland basin: the Atoka Formation of the Arkoma Basin, south-central U.S.A., in Allen, P.A. and Homewood, P. eds., Foreland Basins, Oxford, UK, Blackwell Publishing Ltd, v. 8, p. 327-345.

Hubbard, S.M., Romans, B.W., and Graham, S.A., 2008, Deep-water foreland basin deposits of the Cerro Toro Formation, Magallanes Basin, Chile: Architectural elements of a sinuous basin axial channel belt: Sedimentology, v. 55, p. 13331359, doi:10.1111/j.1365-3091.2007.00948.x.

Ja'Aidi, O.S. Al, McCaffrey, W.D., and Kneller, B.C., 2004, Factors influencing the deposit geometry of experimental turbidity currents: implications for sand-body 
architecture in confined basins, in Lomas, S.A. and Joseph, P. eds., Confined Turbidite Systems. Geological Society, London, Special Publications, London, The Geological Society of London, p. 45-58, http://sp.lyellcollection.org/cgi/doi/10.1144/GSL.SP.2004.222.01.04.

Jobe, Z.R. et al., 2017, High-resolution, millennial-scale patterns of bed compensation on a sand-rich intraslope submarine fan, western Niger Delta slope: Bulletin of the Geological Society of America, v. 129, p. 23-37, doi:10.1130/B31440.1.

Johnson, H.E., 2011, 3D structural analysis of the Benton Uplift, Ouachita Orogen, Arkansas: Texas A\&M University, $238 \mathrm{p}$.

Jones, K.R., and Zachry, D.L., 1994, Storm dominated channel sequences on a shallow marine shelf: Morrowan of northwestern Arkansas: Proceedings Arkansas Academy of Science, v. 48, p. 84-88.

Keller, G.R., and Hatcher, R.D., 1999, Some comparisons of the structure and evolution of the southern Appalachian-Ouachita orogen and portions of the Trans-European suture zone region: Tectonophysics, v. 314, p. 43-68, doi:10.1016/S00401951(99)00236-X.

LaGrange, K.R., 2002, Characterization of the Lower Atoka Formation Arkoma Basin, Central Arkansas: Louisiana State University, 213 p.

Lillie, R.J., Nelson, K.D., Voogd, B. de, Brewer, J.A., Oliver, J.E., Brown, L.D., Kaufman, S., and Viele, G.W., 1983, Crustal Structure of Ouachita Mountains, Arkansas: A Model Based on Integration of COCORP Reflection Profiles and Regional Geophysical Data: AAPG Bulletin, v. 67, p. 907-931, doi:10.1306/03B5B6CD-16D1-11D7-8645000102C1865D.

Liu, Q., Kneller, B.C., Fallgatter, C., Buso, V.V., and Milana, J.P., 2018, Tabularity of individual turbidite beds controlled by flow efficiency and degree of confinement: Sedimentology, v. 65, p. 2368-2387, doi:10.1111/sed.12470.

Lomas, S.A., and Joseph, P., 2004, Confined turbidite systems, in Lomas, S.A. and Joseph, P. eds., Confined Turbidite Systems. Geological Society, London, Special Publications, London, The Geological Society of London, v. 222, p. 1-7.

Lowe, D.R., 1979, Sediment gravity flows: their classification and some problems of application to natural flows and deposits, in Geology of Continental Slopes, SEPM (Society for Sedimentary Geology), p. 75-82, doi:10.2110/pec.79.27.0075.

Malinverno, A., 1997, On the power law size distribution of turbidite beds: Basin Research, v. 9, p. 263-274, doi:10.1046/j.1365-2117.1997.00044.x.

Marini, M., Felletti, F., Milli, S., and Patacci, M., 2016a, The thick-bedded tail of turbidite thickness distribution as a proxy for flow confinement: examples from Tertiary basins of central and northern Apennines (Italy): Sedimentary Geology, v. 341, p. 96-118, doi:10.1016/j.sedgeo.2016.05.006.

Marini, M., Milli, S., Ravnås, R., and Moscatelli, M., 2015, A comparative study of confined vs. semi-confined turbidite lobes from the Lower Messinian Laga Basin 
(Central Apennines, Italy): Implications for assessment of reservoir architecture: Marine and Petroleum Geology, v. 63, p. 142-165, doi:10.1016/j.marpetgeo.2015.02.015.

Marini, M., Patacci, M., Felletti, F., and Mccaffrey, W.D., 2016b, Fill to spill stratigraphic evolution of a confined turbidite mini-basin succession, and its likely well bore expression: The Castagnola Fm, NW Italy: Marine and Petroleum Geology, v. 69, p. 94-111, doi:10.1016/j.marpetgeo.2015.10.014.

Mickus, K.L., and Keller, G.R., 1992, Lithospheric Structure of the South-Central United-States: Geology, v. 20, p. 335-338, doi:10.1130/00917613(1992)020<0335:1sotsc >2.3.co;2.

Moody, J.D., Pyles, D.R., Clark, J., and Bouroullec, R., 2012, Quantitative outcrop characterization of an analog to weakly confined submarine channel systems: Morillo 1 member, Ainsa Basin, Spain: AAPG Bulletin, v. 96, p. 1813-1841, doi:10.1306/01061211072.

Morley, C.K., King, R., Hillis, R., Tingay, M., and Backe, G., 2011, Deepwater fold and thrust belt classification, tectonics, structure and hydrocarbon prospectivity: A review: Earth-Science Reviews, v. 104, p. 41-91, doi:10.1016/j.earscirev.2010.09.010.

Morris, R.C., 1974a, Carboniferous rocks of the Ouachita Mountains, Arkansas: A study of facies patterns along the unstable slope and axis of a flysch trough: Geological Society of America Bulletin, v. 148, p. 241-280, doi:10.1130/SPE148-p241.

Morris, R.C., 1974b, Sedimentary and tectonic history of the Ouachita Mountains, in Tectonics and Sedimentation, SEPM (Society for Sedimentary Geology), v. 22, p. 120-142, doi:10.2110/pec.74.22.0120.

Morris, R.C., 1971, Stratigraphy and sedimentology of Jackfork Group, Arkansas: American Association of Petroleum Geologists Bulletin, v. 55, p. 387-402, doi:10.1306/5D25CF61-16C1-11D7-8645000102C1865D.

Mutti, E., 1985, Turbidite systems and their relations to depositional sequences, in Zuffa, G.G. ed., Provenance of arenites, Cosenza, D. Reidel Publishing Company, p. 6593, http://link.springer.com/10.1007/978-94-017-2809-6.

Mutti, E., and Normark, W.R., 1987, Comparing Examples of Modern and Ancient Turbidite Systems: Problems and Concepts, in Leggett, J.K. and Zuffa, G.G. eds., Marine Clastic Sedimentology: Concepts and Case Studies, Dordrecht, Springer Netherlands, p. 1-38, doi:10.1007/978-94-009-3241-8_1.

Mutti, E., Tinterri, R., Benevelli, G., Biase, D. di, and Cavanna, G., 2003, Deltaic, mixed and turbidite sedimentation of ancient foreland basins: Marine and Petroleum Geology, v. 20, p. 733-755, doi:10.1016/j.marpetgeo.2003.09.001.

Nelson, K.D., Lillie, R.J., Voogd, B. de, Brewer, J.A., Oliver, J.E., Kaufman, S., Brown, L., and Viele, G.W., 1982, COCORP seismic reflection profiling in the Ouachita 
Mountains of western Arkansas: Geometry and geologic interpretation: Tectonics, v. 1, p. 413-430, doi:10.1029/TC001i005p00413.

Nilsen, T.H., Shew, R.D., Steffens, G.S., and Studlick, J.R.J. (Eds.), 2007, Atlas of deepwater outcrops - AAPG Studies in Geology 36: Tulsa, Oklahoma, American Association of Petroleum Geologists, 504 p.

Nyberg, B., Helland-Hansen, W., Gawthorpe, R.L., Sandbakken, P., Eide, C.H., Sømme, T., Hadler-Jacobsen, F., and Leiknes, S., 2018, Revisiting morphological relationships of modern source-to-sink segments as a first-order approach to scale ancient sedimentary systems: Sedimentary Geology, v. 373, p. 111-133, doi:10.1016/j.sedgeo.2018.06.007.

Palozzi, J., Pantopoulos, G., Maravelis, A.G., Nordsvan, A., and Zelilidis, A., 2018, Sedimentological analysis and bed thickness statistics from a Carboniferous deepwater channel-levee complex: Myall Trough, SE Australia: Sedimentary Geology, v. 364, p. 160-179, doi:10.1016/j.sedgeo.2017.12.019.

Pantopoulos, G., Kneller, B.C., McArthur, A.D., Courivaud, S., Grings, A.E., and Kuchle, J., 2018, Turbidite bed thickness statistics of architectural elements in a deepmarine confined mini-basin setting: Examples from the Grès d'Annot Formation, SE France: Marine and Petroleum Geology, v. 95, p. 16-29, doi:10.1016/j.marpetgeo.2018.04.008.

Patacci, M., Haughton, P.D.W., and Mccaffrey, W.D., 2015, Flow Behavior of Ponded Turbidity Currents: Journal of Sedimentary Research, v. 85, p. 885-902, doi:10.2110/jsr.2015.59.

Pettinga, L., Jobe, Z., Shumaker, L., and Howes, N., 2018, Morphometric scaling relationships in submarine channel-lobe systems: Geology, v. 46, p. 819-822, doi:10.1130/G45142.1.

Pickering, K.T., and Hiscott, R.N., 1985, Contained (reflected) turbidity currents from the Middle Ordovician Cloridorme Formation, Quebec, Canada: an alternative to the antidune hypothesis: Sedimentology, v. 32, p. 373-394, doi:10.1002/9781444304473.ch7.

Pickering, K.T., and Hiscott, R.N., 2016, Deep Marine Systems: Processes, Deposits, Environments, Tectonics and Sedimentation: Chichester, West Sussex, UK; Hoboken, NJ, American Geophysical Union \& Wiley, 657 p.

Prather, B.E., Keller, F.B., and Chapin, M.A., 2000, Hierarchy of deep-water architectural elements with reference to seismic resolution: implications for reservoir prediction and modeling, in Weimer, P., Slatt, R.M., Coleman, J.L., Rosen, N.C., Nelson, C.H., Bouma, A.H., Styzen, M.J., and Lawrence, D.T. eds., GCSSEPM Foundation 20th Annual Research Conference, Deep-Water Reservoirs of the World, Houston, TX, Gulf Coast Section Society of Economic Paleontologists and Mineralogists Foundation, p. 817-835. 
Prélat, A., Covault, J.A., Hodgson, D.M., Fildani, A., and Flint, S.S., 2010, Intrinsic controls on the range of volumes, morphologies, and dimensions of submarine lobes: Sedimentary Geology, v. 232, p. 66-76, doi:10.1016/j.sedgeo.2010.09.010.

Prélat, A., Hodgson, D.M., and Flint, S.S., 2009, Evolution, architecture and hierarchy of distributary deep-water deposits: a high-resolution outcrop investigation from the Permian Karoo Basin, South Africa: Sedimentology, v. 56, p. 2132-2154, doi:10.1111/j.1365-3091.2009.01073.x.

Pyles, D.R. et al., 2008, Multiscale stratigraphic analysis of a structurally confined submarine fan: Carboniferous Ross Sandstone, Ireland: AAPG Bulletin, v. 92, p. 557-587, doi:10.1306/01110807042.

Pyles, D.R., 2008, Multiscale stratigraphic analysis of a structurally confined submarine fan: Carboniferous Ross Sandstone, Ireland: AAPG Bulletin, v. 92, p. 557-587, doi:10.1306/01110807042.

Ravnås, R., and Steel, R.J., 1998, Architecture of Marine Rift-Basin Successions: AAPG Bulletin, v. 82, p. 110-146, doi:10.1306/1D9BC3A9-172D-11D7$8645000102 \mathrm{C} 1865 \mathrm{D}$.

Romans, B.W., Castelltort, S., Covault, J.A., Fildani, A., and Walsh, J.P., 2016, Environmental signal propagation in sedimentary systems across timescales: Earth-Science Reviews, v. 153, p. 7-29, doi:10.1016/j.earscirev.2015.07.012.

Romans, B.W., Fildani, A., Hubbard, S.M., Covault, J.A., Fosdick, J.C., and Graham, S.A., 2011, Evolution of deep-water stratigraphic architecture, Magallanes Basin, Chile: Marine and Petroleum Geology, v. 28, p. 612-628, doi:10.1016/j.marpetgeo.2010.05.002.

Romans, B.W., Hubbard, S.M., and Graham, S.A., 2009, Stratigraphic evolution of an outcropping continental slope system, Tres Pasos Formation at Cerro Divisadero, Chile: Sedimentology, v. 56, p. 737-764, doi:10.1111/j.1365-3091.2008.00995.x.

Sharrah, K.L., 2006, Comparative Study and Provenance of the Atoka Formation in the Frontal Ouachita Thrust Belt, Oklahoma: University of Tulsa, 268 p., doi:10.3102/00346543067001043.

Shaulis, B.J., Lapen, T.J., Casey, J.F., and Reid, D.R., 2012, Timing and rates of flysch sedimentation in the Stanley Group, Ouachita Mountains, Oklahoma and Arkansas, U.S.A.: Constraints from U-Pb zircon ages of subaqueous ash-flow tuffs: Journal of Sedimentary Research, v. 82, p. 833-840.

Sinclair, H.D., and Cowie, P.A., 2003, Basin-Floor Topography and the Scaling of Turbidites: The Journal of Geology, v. 111, p. 277-299, doi:10.1086/373969.

Sinclair, H.D., and Tomasso, M., 2002, Depositional Evolution of Confined Turbidite Basins: Journal of Sedimentary Research, v. 72, p. 451-456, doi:10.1306/111501720451. 
Slatt, R.M., Stone, C.G., and Weimer, P., 2000, Characterization of slope and basin facies tracts, Jackfork Group, Arkansas, with applications to deepwater (turbidite) reservoir management, in Weimer, P., Slatt, R.M., Coleman, J.L., Rosen, Norman, C., Nelson, C.H., Bouma, A.H., Styzen, M.J., and Lawrence, D.T. eds., GCSSEPM Foundation 20th Annual Research Conference, Deep-Water Reservoirs of the World, Houston, TX, TX, Gulf Coast Section Society of Economic Paleontologists and Mineralogists Foundation, p. 940-980.

Sprague, A.R.G., 1985, Depositional environment and petrology of the lower member of the Pennsylvanian Atoka Formation, Ouachita Mountains, Arkansas and Oklahoma: The University of Texas at Dallas, 587 p.

Spychala, Y.T., Hodgson, D.M., Prélat, A., Kane, I.A., Flint, S.S., and Mountney, N.P., 2017, Frontal and Lateral Submarine Lobe Fringes: Comparing Sedimentary Facies, Architecture and Flow Processes: Journal of Sedimentary Research, v. 87, p. 75-96, doi:10.2110/jsr.2017.2.

Stone, C.G., and Haley, B.R., 1984, A Guidebook to the Geology of the Central and Southern Ouachita Mountains, Arkansas: Arkansas Geological Commission Guidebook 84-2.:

Straub, K.M., Paola, C., Mohrig, D., Wolinsky, M. a., and George, T., 2009, Compensational Stacking of Channelized Sedimentary Deposits: Journal of Sedimentary Research, v. 79, p. 673-688, doi:10.2110/jsr.2009.070.

Straub, K.M., and Pyles, D.R., 2012, Quantifying the hierarchical organization of compensation In submarine fans using surface statistics: Journal of Sedimentary Research, v. 82, p. 889-898, doi:10.2110/jsr.2012.73.

Suneson, N.H., 2012, Arkoma Basin petroleum: past, present, and future: Shale Shaker Digest, v. 63, p. 38-70.

Suneson, N.H. (Ed.), 2008, Stratigraphic and structural evolution of the Ouachita Mountains and Arkoma Basin, southeastern Oklahoma and west-central Arkansas: applications to petroleum exploration: 2004 field symposium (the ArbenzMisch/Oles Volume): Norman, Oklahoma, Oklahoma Geological Survey, 92 p.

Sylvester, Z., 2007, Turbidite bed thickness distributions: methods and pitfalls of analysis and modelling: Sedimentology, v. 54, p. 847-870, doi:10.1111/j.13653091.2007.00863.x.

Talling, P.J., 2002, On the frequency distribution of turbidite thickness: Sedimentology, v. 48, p. 1297-1329, doi:10.1046/j.1365-3091.2001.00423.x.

Thomas, W.A., 2004, Genetic relationship of rift-stage crustal structure, terrane accretion, and foreland tectonics along the southern Appalachian-Ouachita orogen: Journal of Geodynamics, v. 37, p. 549-563, doi:10.1016/j.jog.2004.02.020.

Thomas, W.A., 1997, Nd isotopic constraints on sediment sources of the OuachitaMarathon fold belt: Alternative Interpretation and Reply Alternative 
Interpretation: Geological Society of America Bulletin, v. 109, p. 1192-1210, doi:10.1130/0016-7606(1997)109<0779.

Thomas, W.A., 2011, The Iapetan rifted margin of southern Laurentia: Geosphere, v. 7, p. 97-120, doi:10.1130/GES00574.1.

Tökés, L., and Patacci, M., 2018, Quantifying tabularity of turbidite beds and its relationship to the inferred degree of basin confinement: Marine and Petroleum Geology, v. 97, p. 659-671, doi:10.1016/j.marpetgeo.2018.06.012.

Tversky, A., and Kahneman, D., 1971, Belief in the law of small numbers.: Psychological Bulletin, v. 76, p. 105-110, doi:10.1037/h0031322.

Viele, G.W., and Thomas, W.A., 1989, Tectonic synthesis of the Ouachita orogenic belt, in Hatcher, R.D., Thomas, W.A., and Viele, G.W. eds., The AppalachianOuachita Orogen in the United States, Norman, Oklahoma, Oklahoma, Geological Society of America, p. 695-728.

Walker, R.G., 1978, Deep-Water Sandstone Facies and Ancient Submarine Fans: Models for Exploration for Stratigraphic Traps: AAPG Bulletin, v. 62, p. 932-966, doi:10.1306/C1EA4F77-16C9-11D7-8645000102C1865D.

Walthall, B.H., 1967, Stratigraphy and Structure, Part of Athens Plateau, Southern Ouachitas, Arkansas: AAPG Bulletin, v. 51, p. 120, doi:10.1306/5D25C0A116C1-11D7-8645000102C1865D.

Xu, C., Cronin, T.P., McGinness, T.E., and Steer, B., 2009, Middle Atokan sediment gravity flows in the Red Oak field, Arkoma Basin, Oklahoma: A sedimentary analysis using electrical borehole images and wireline logs: AAPG Bulletin, v. 93, p. 1-29, doi:10.1306/09030808054.

Zachry, D.L., 1979, Early Pennsylvanian braided stream sedimentation, northwest Arkansas, in Hyne, N.J. ed., Pennsylvanian Sandstones of the Mid-Continent: Tulsa Geological Society Special Publication No. 1, Tulsa, Oklahoma, Tulsa Geological Society, p. 269-281.

Zachry, D.L., and Sutherland, P.K., 1984, Stratigraphy and depositional framework of the Atoka Formation (Pennsylvanian), Arkoma Basin of Arkansas and Oklahoma: The Atokan Series (Pennsylvanian) and its boundaries: a symposium. Oklahoma Geological Survey Bulletin, v. 136, p. 9-17.

Zou, F., Slatt, R.M., Bastidas, R., and Ramirez, B., 2012, Integrated outcrop reservoir characterization, modeling, and simulation of the Jackfork Group at the Baumgartner Quarry area, western Arkansas: implications to Gulf of Mexico deep-water exploration and production: American Association of Petroleum Geologists Bulletin, v. 96, p. 1429-1448, doi:10.1306/01021210146.

Zou, F., Slatt, R.M., Zhang, J., and Huang, T., 2017, An integrated chemo-and sequencestratigraphic framework of the Early Pennsylvanian deepwater outcrops near Kirby, Arkansas, USA, and its implications on remnant basin tectonics: Marine and Petroleum Geology, v. 81, p. 252-277, doi:10.1016/j.marpetgeo.2017.01.006. 


\section{Figures}

(color is not needed for figures in print)

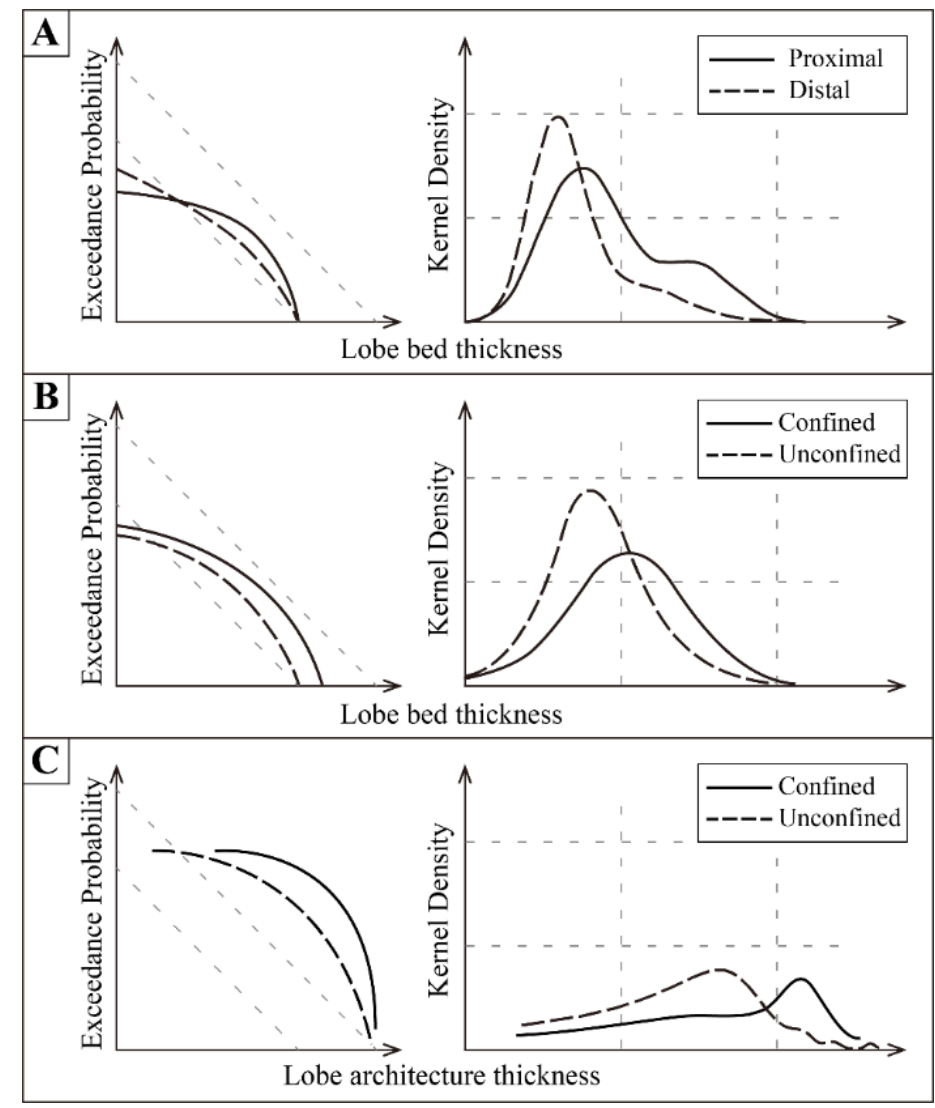

Fig. 1 Generalized exceedance cumulative probability distributions (ECDF) and kernel density estimations (KDE) of bed thickness in turbidite lobes and lobe architecture thicknesses. (A) shows the proximal-distal trend of bed thickness distributions in unconfined setting (after Carlson and Grotzinger, 2001; Sinclair et al., 2016; Pantopoulos et al., 2018). (B) shows the contrast of bed thickness distributions in confined and unconfined setting (after Fryer and Jobe, 2018). (C) shows the contrast of the distributions of lobe architecture thickness in confined and unconfined setting (after Prélat et al., 2010; Pettinga et al., 2018). ECDF plots are log-log scale. KDE plots are log-linear scale. Thickness, probability, kernel density not to scale. 

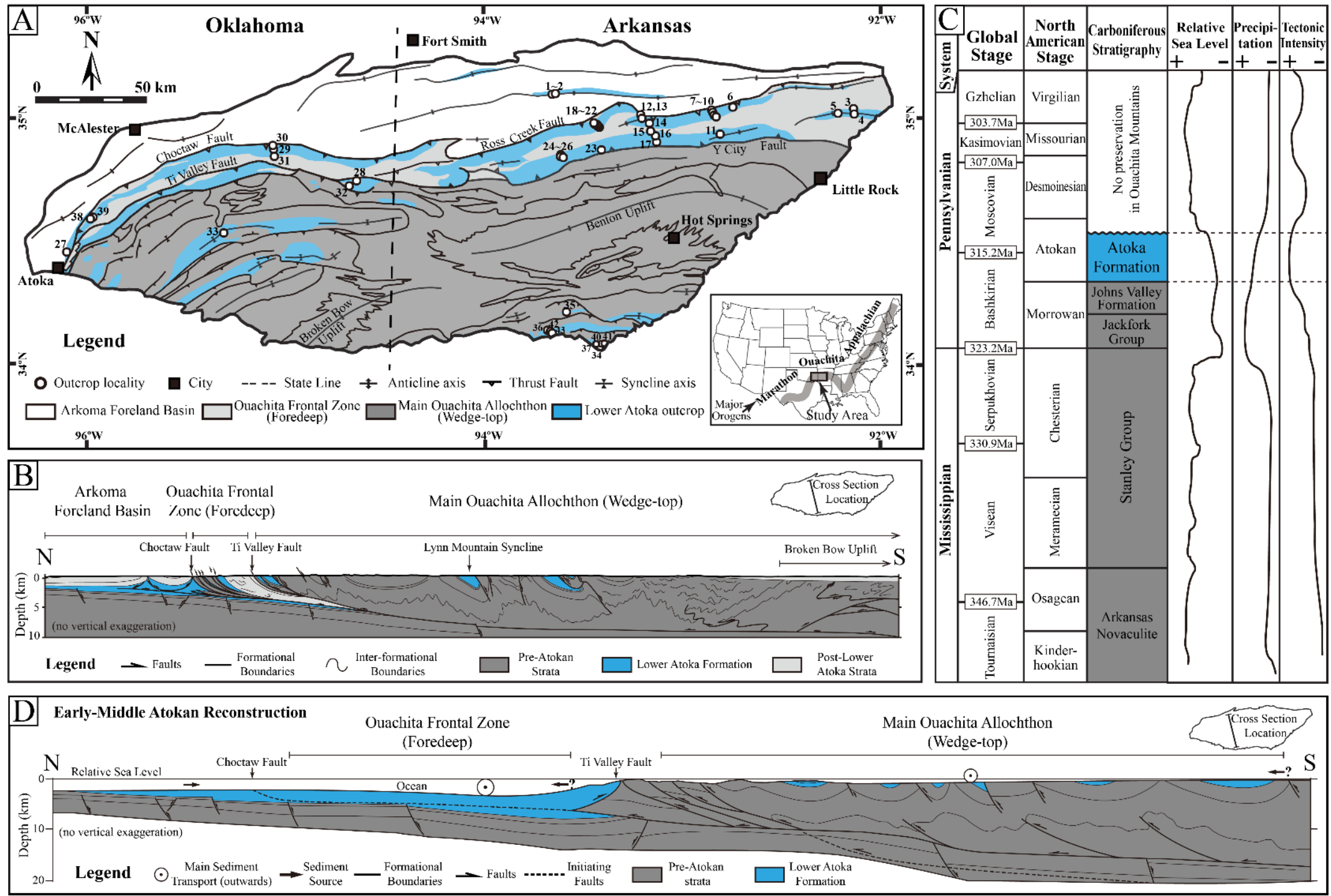
Fig. 2 A) Simplified geologic map of the Ouachita Mountains showing the outcrop localities of the Lower Atoka Formation and the 3 structural zones: Arkoma Foreland Basin, Ouachita Frontal Zone (Foredeep), and Main Ouachita Allochthon (Wedge-top) (after Arbenz, 2008). Detailed information of the localities is listed in supplementary data table SDT 1. B) A north-south geological cross-section showing the major lithospheric structures of the study area (after Arbenz, 2008; Suneson, 2008, 2012). C) Stratigraphic chart, relative sea level, precipitation, and tectonic intensity of the Carboniferous in the Ouachita Mountains (after Coleman, 2000; Heckel and Clayton, 2006). D) A reconstructed geological cross-section of the Ouachita Mountains during Early-Middle Atokan ( $c$ 3 315Ma) showing the contrasting structural styles of the Ouachita Frontal Zone and the Main Allochthon (after Arbenz, 2008). 


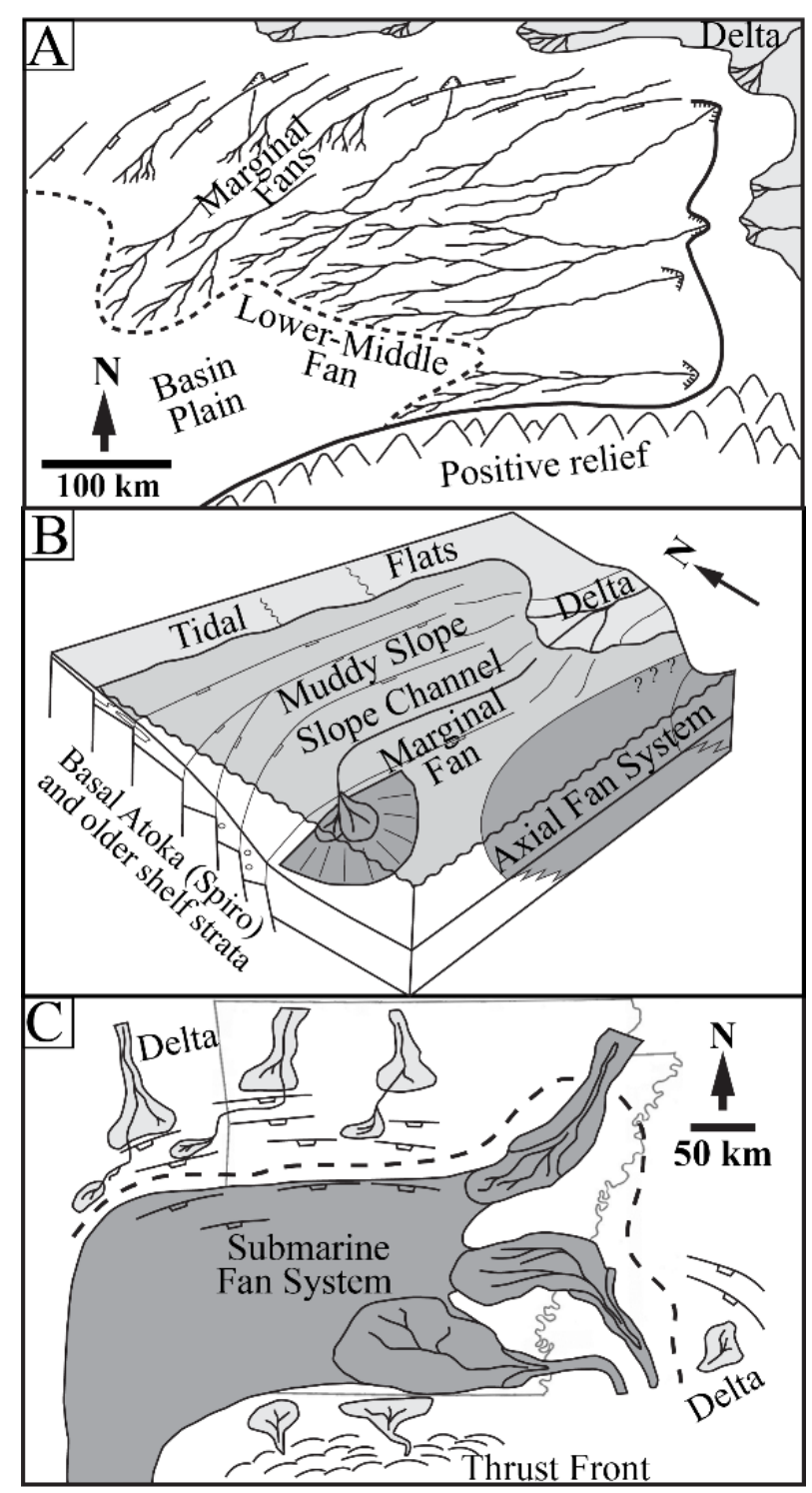

Fig. 3 Depositional models proposed for the Pennsylvanian Atoka Formation in the Arkoma Basin and the Ouachita Mountains. A: a depositional model for the Lower Atoka Formation showing a predominant east-to-west sediment dispersal system (after Sprague, 1985); B: a depositional model for the Atoka Formation showing the co-existence of an axial fan and a slope (marginal) fan systems in the Arkoma Basin (after Houseknecht, 1986); C: synthesized depositional model showing the basin shape and potential sources (after Coleman, 2000). 


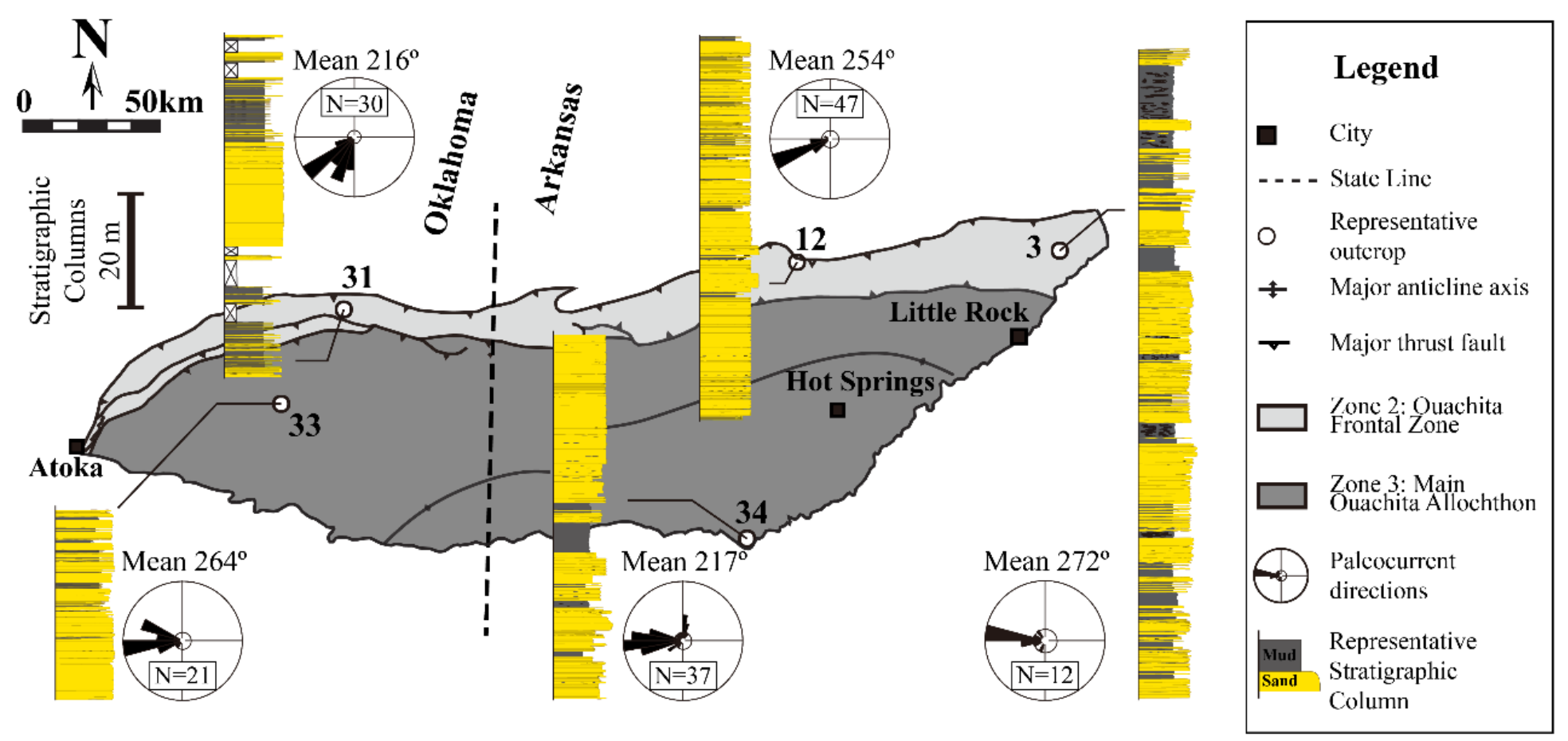

Fig. 4 Representative measured sections of the Lower Atoka Formation from the foredeep (light grey on map) and wedge-top (dark grey on map) depozones. The general sediment transport direction is from east to west, as illustrated by the paleocurrent directions measured from flute casts. All digitized measured sections and interpretations are tabulated in the supplementary data table SDT 2. 


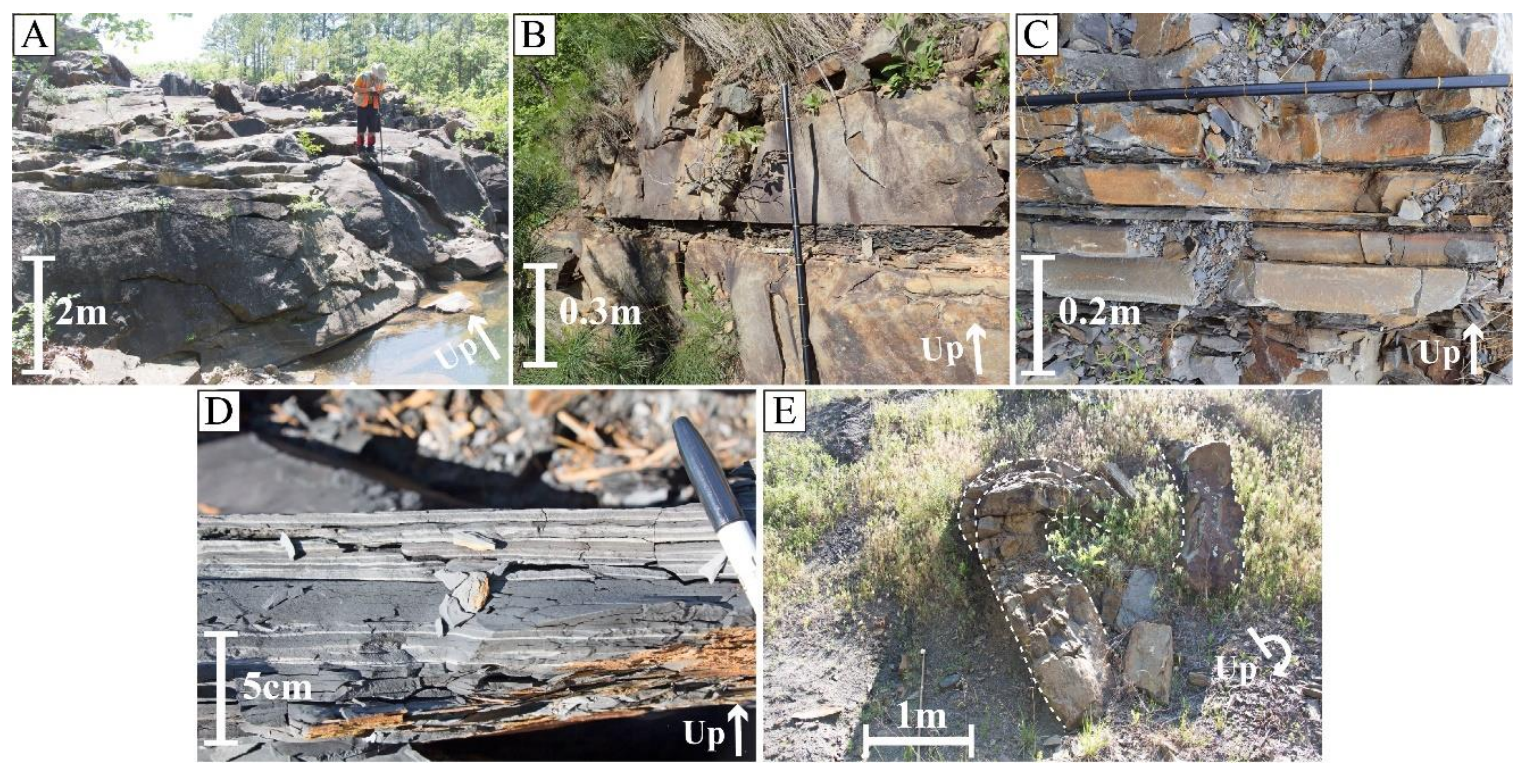

Fig. 5 Lithofacies recognized in this study. A) massive, amalgamated sandstone; B) thick-bedded sandstone with minor mudstone; C) thin-bedded sandstone-mudstone; D) mudstone with minor sandstone; E) chaotically bedded mudstone-sandstone. 


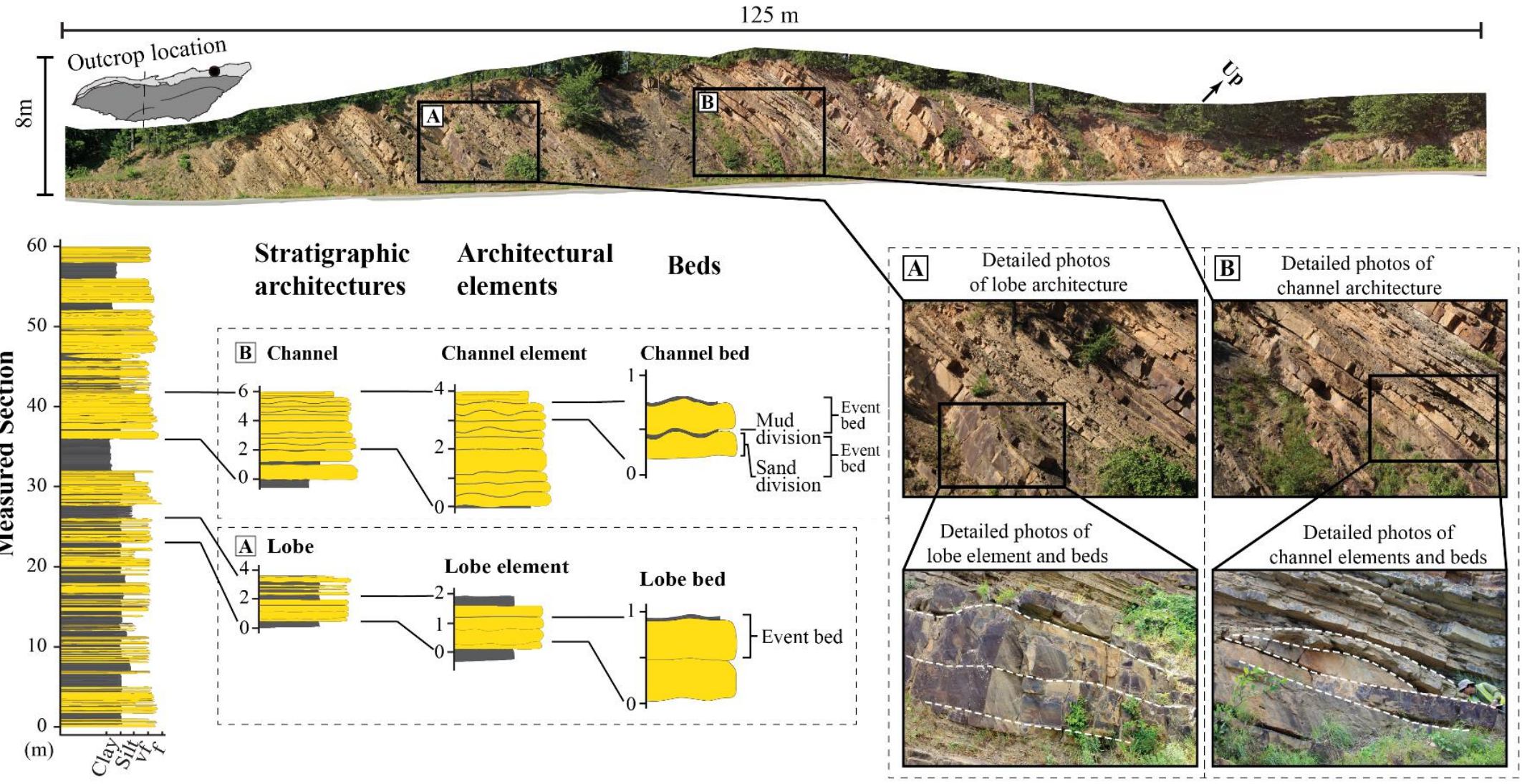

Fig. 6 An example of the outcrop and measured section showing the recognition of facies hierarchy in this study. The outcrop is situated at AR Highway 9/10 between Perry and Perryville in Perry County, Arkansas. 

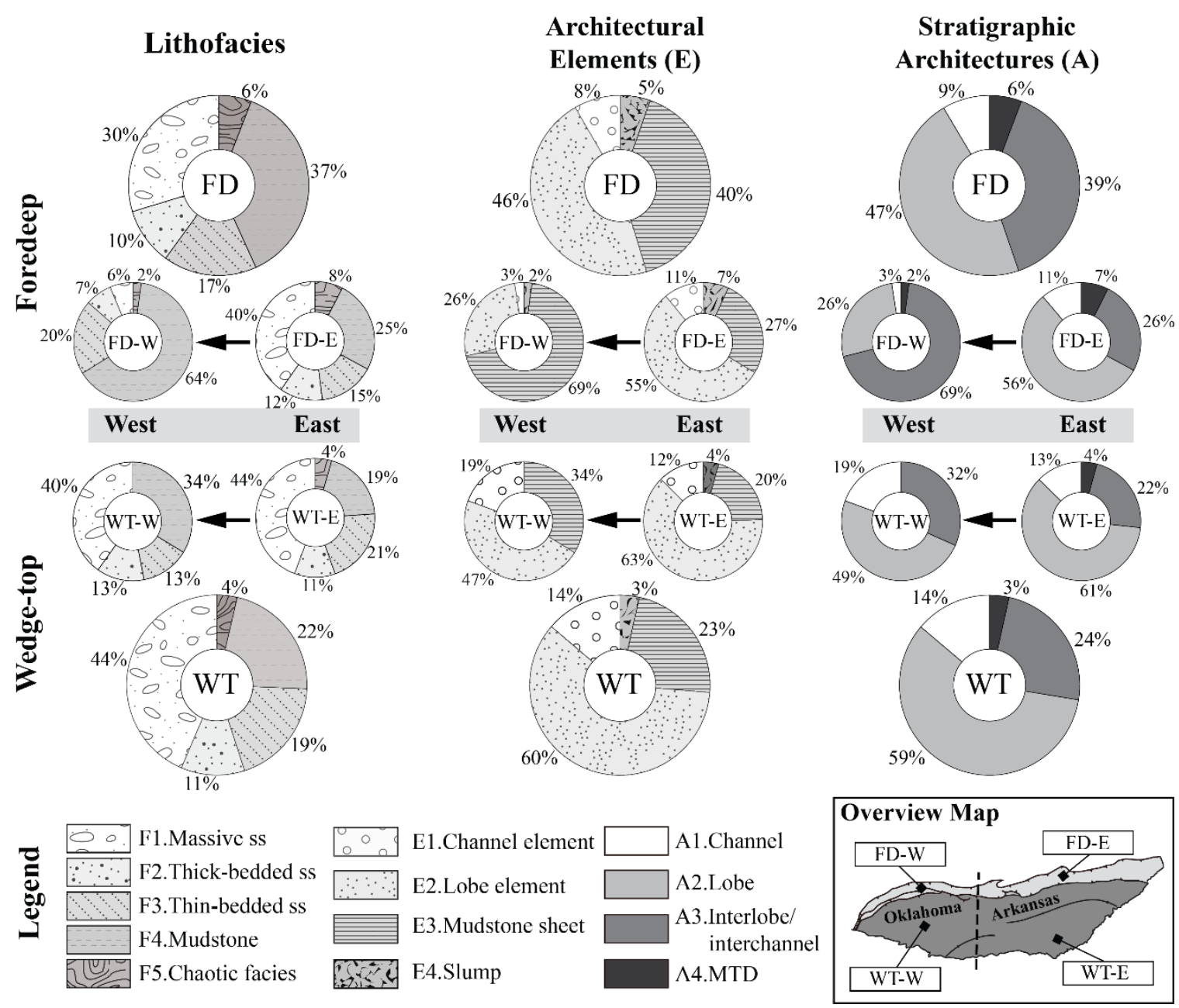

Fig. 7 Pie charts showing the thickness proportions of each lithofacies, architectural element, and stratigraphic architecture in the Foredeep (FD) and Wedge-top (WT) depozones. The large pie charts show the contrast between the entire FD and WT at each hierarchical scale. The small pie charts show the longitudinal changes from the east (proximal) to the west (distal). The longitudinal changes in the foredeep (FD-E to FD-W) are noticeably greater than those in Wedge-top (WT-E to WT-W) at all hierarchical scales. Meanwhile, there is subtle lateral (north-south) variation between the two depozones in the east (FD-E and WT-E), but significant variations in the west (FD-W and WT-W) at all hierarchical scales. 

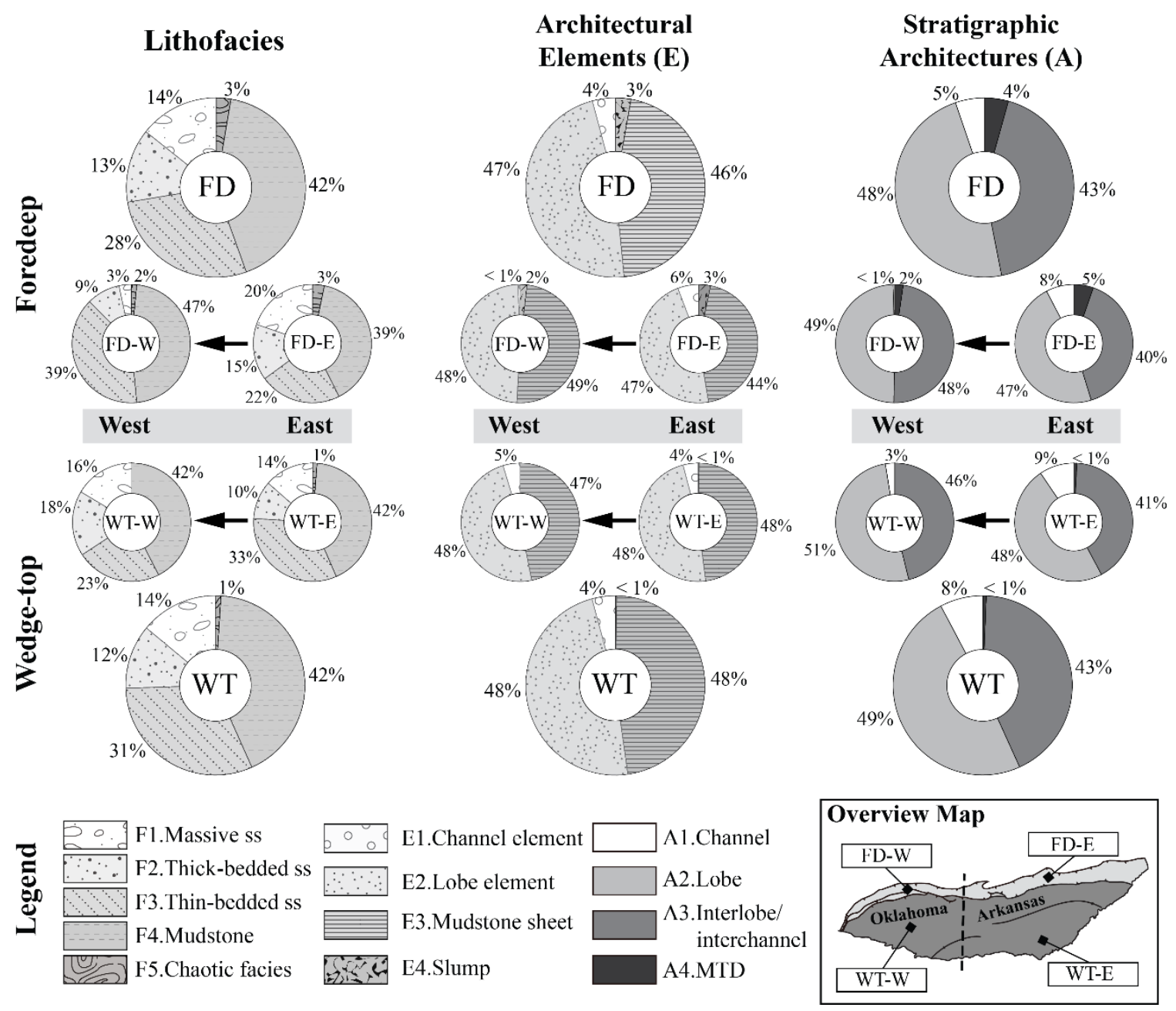

Architectures (A)
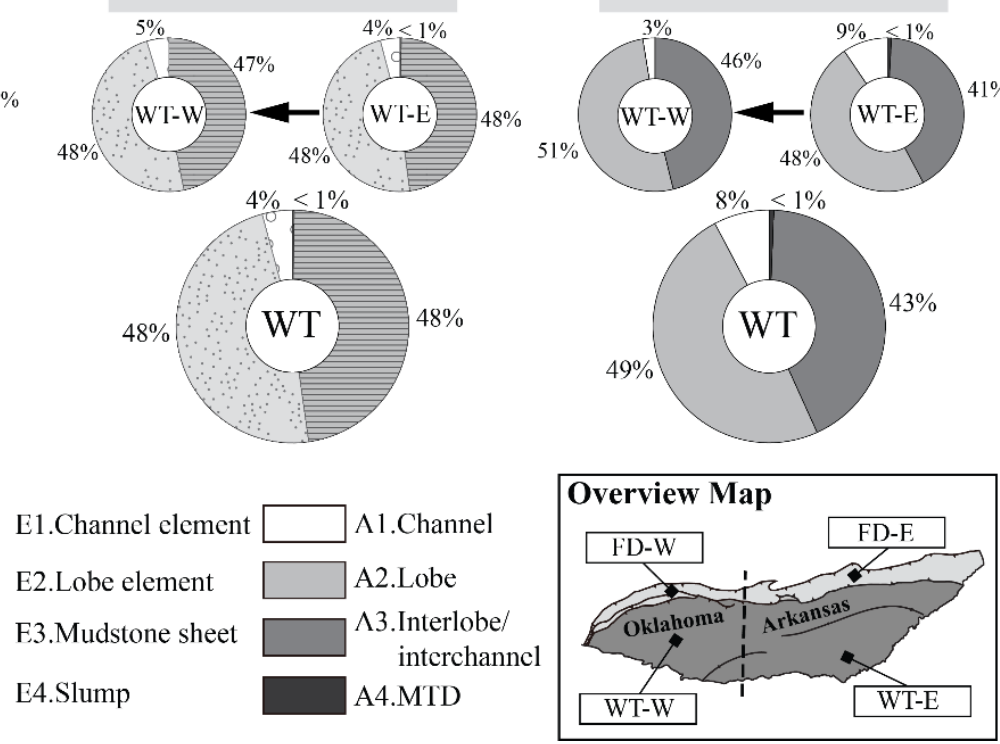

Fig. 8 Pie charts showing the relative frequency of occurrences on all types of lithofacies, architectural elements, and stratigraphic architectures in the foredeep (FD) and Wedgetop (WT) depozones. The large pie charts show the contrast between the entire FD and WT at each hierarchical scale. The small pie charts show the longitudinal changes from the east (proximal) to the west (distal). The longitudinal variations are slightly greater in the foredeep (FD-E to FD-W) than those in the wedge-top (WT-E to WT-W). There are barely any lateral (north-south) variations except for lithofacies in the west. 


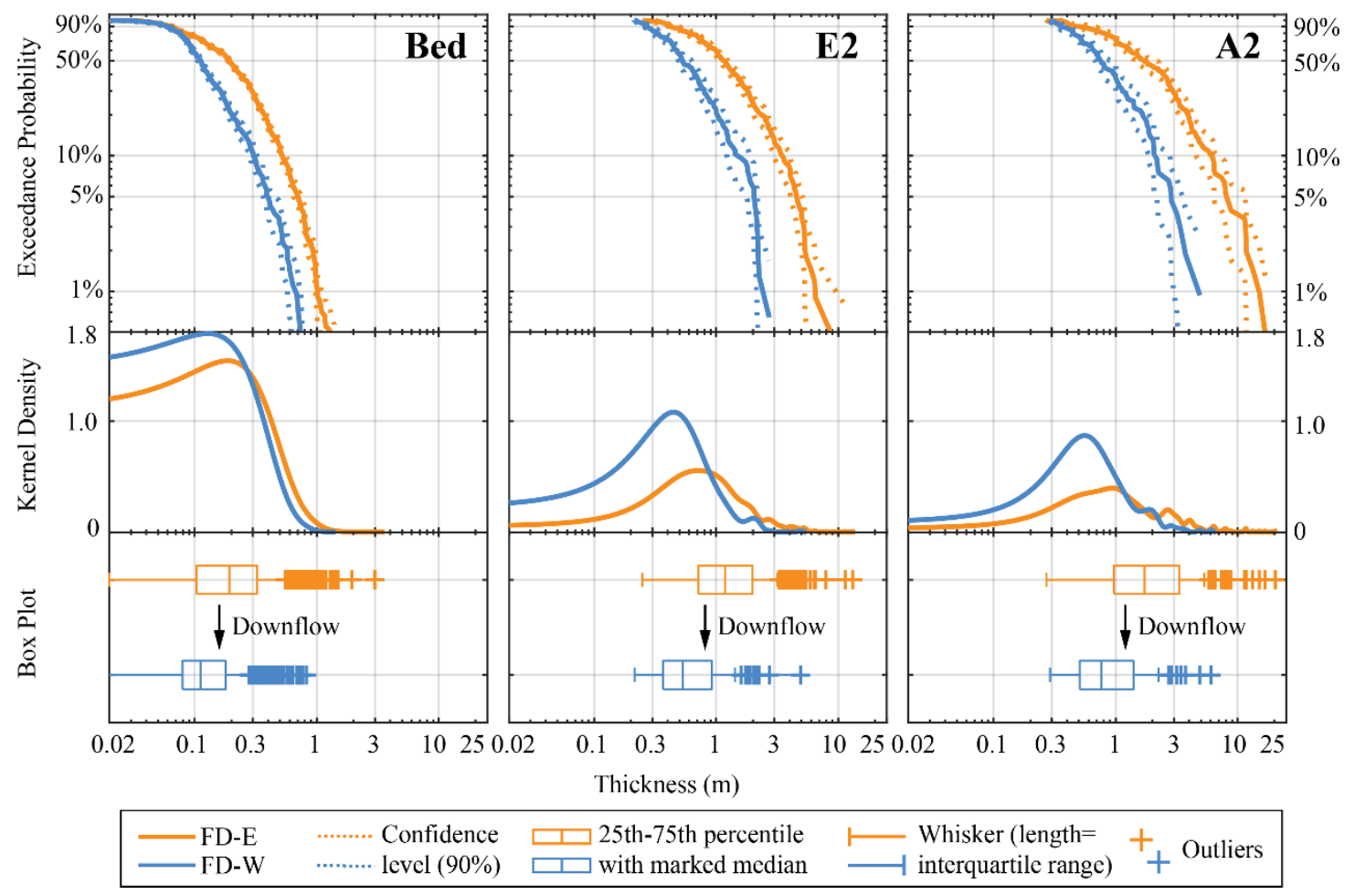

Fig. 9 Longitudinal variations in the foredeep depozone (FD) expressed in exceedance $\mathrm{CDF}$, kernel density estimation, and boxplots. The proximal portion (FD-E) is consistently thicker than the distal portion (FD-W) at all hierarchical scales. The longitudinal variations concur with the facies trends in Fig. 8Fig. 9 and classical turbidite facies models (Walker, 1978; Bouma et al., 1985; Mutti, 1985; Mutti and Normark, 1987). 


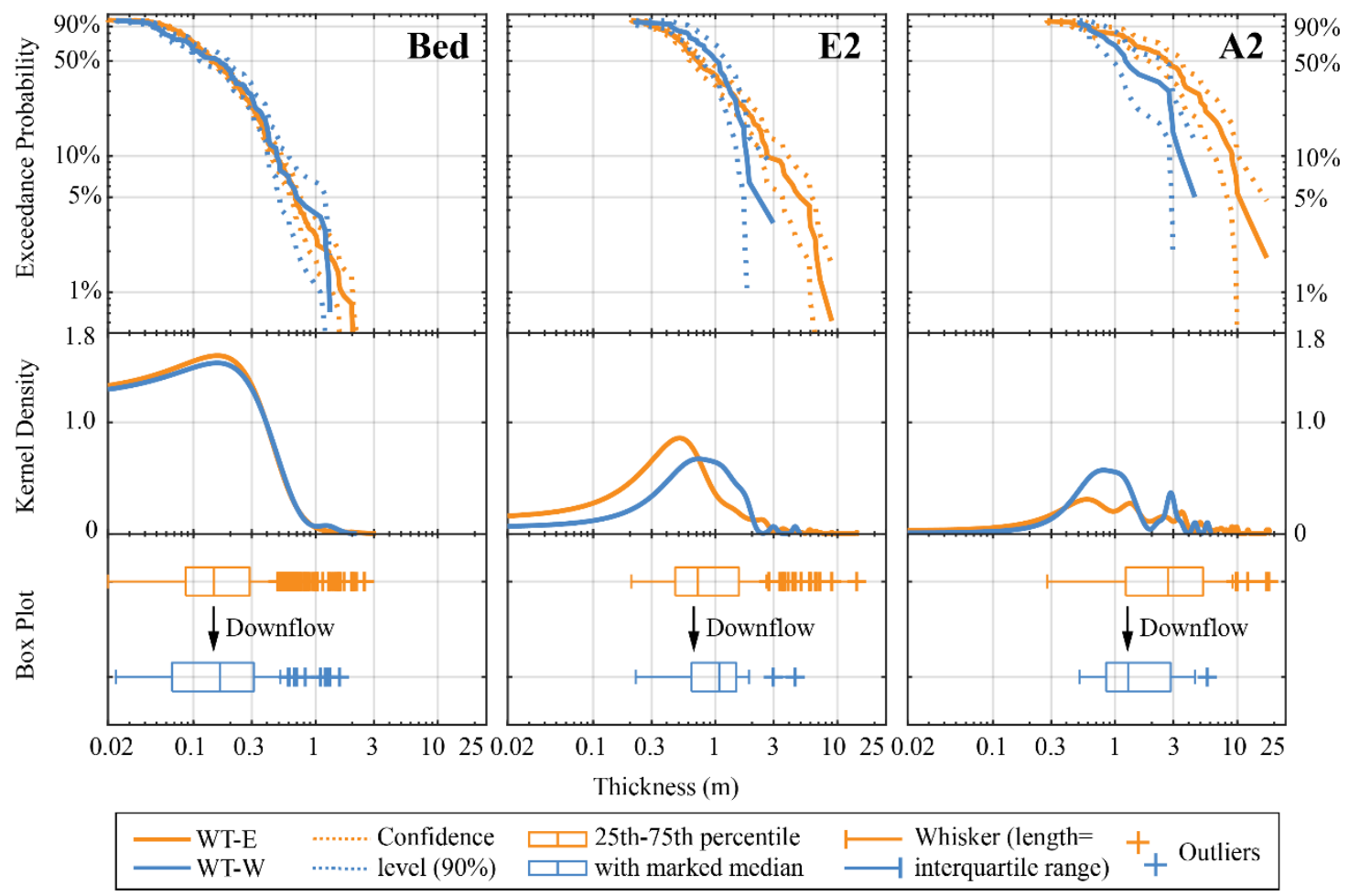

Fig. 10 Longitudinal variations in the wedge-top depozone (WT) expressed in exceedance $\mathrm{CDF}$, kernel density estimation, and boxplots. The thickness distributions show little difference between the proximal (WT-E) and distal (WT-W) portions at the bed scale. However, the WT-E shows greater thickness than WT-W with increasing hierarchy. The reason is most likely that stronger compensational stacking in the distal portion (Straub et al., 2009; Straub and Pyles, 2012) restrained the over-thickening of lobe deposits despite lateral confinement. 


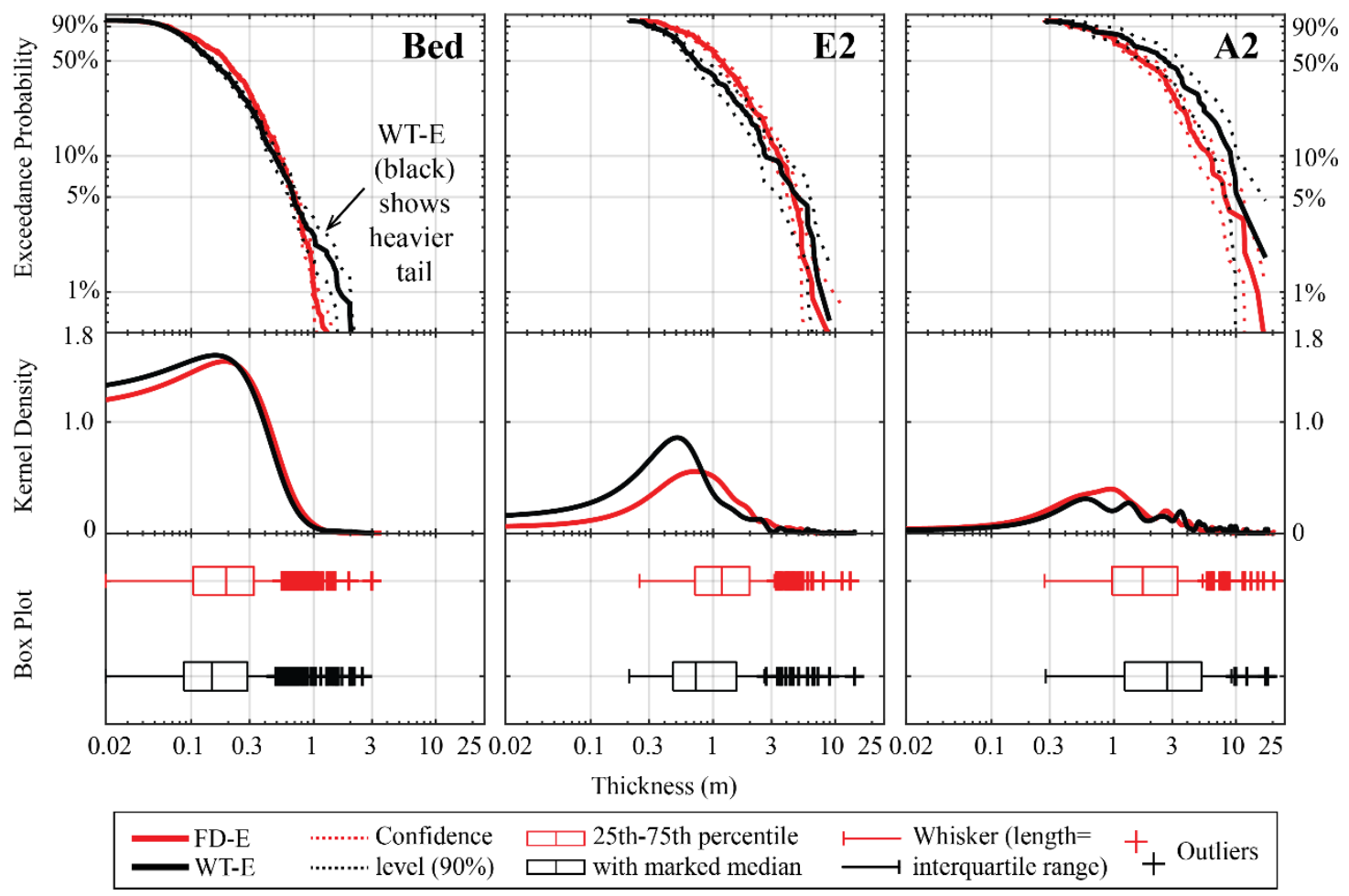

Fig. 11 Lateral variations in the proximal portions of the foredeep (FD-E) and wedge-top (WT-E) depozones in the study area expressed in exceedance CDF, kernel density estimation, and boxplots. At the bed and lobe element (E2) scales, the thickness distributions are similar can hardly be distinguished with $90 \%$ confidence level, which reflects the influence of common sediment supply (also see the similarity between FD-E and WT-E in Fig. 8Fig. 9). At the lobe (A2) scale, the wedge-top shows greater thickness and higher mean, which reflects the magnified signal of topographic confinement in WT with increasing hierarchy (see section 5.4). 


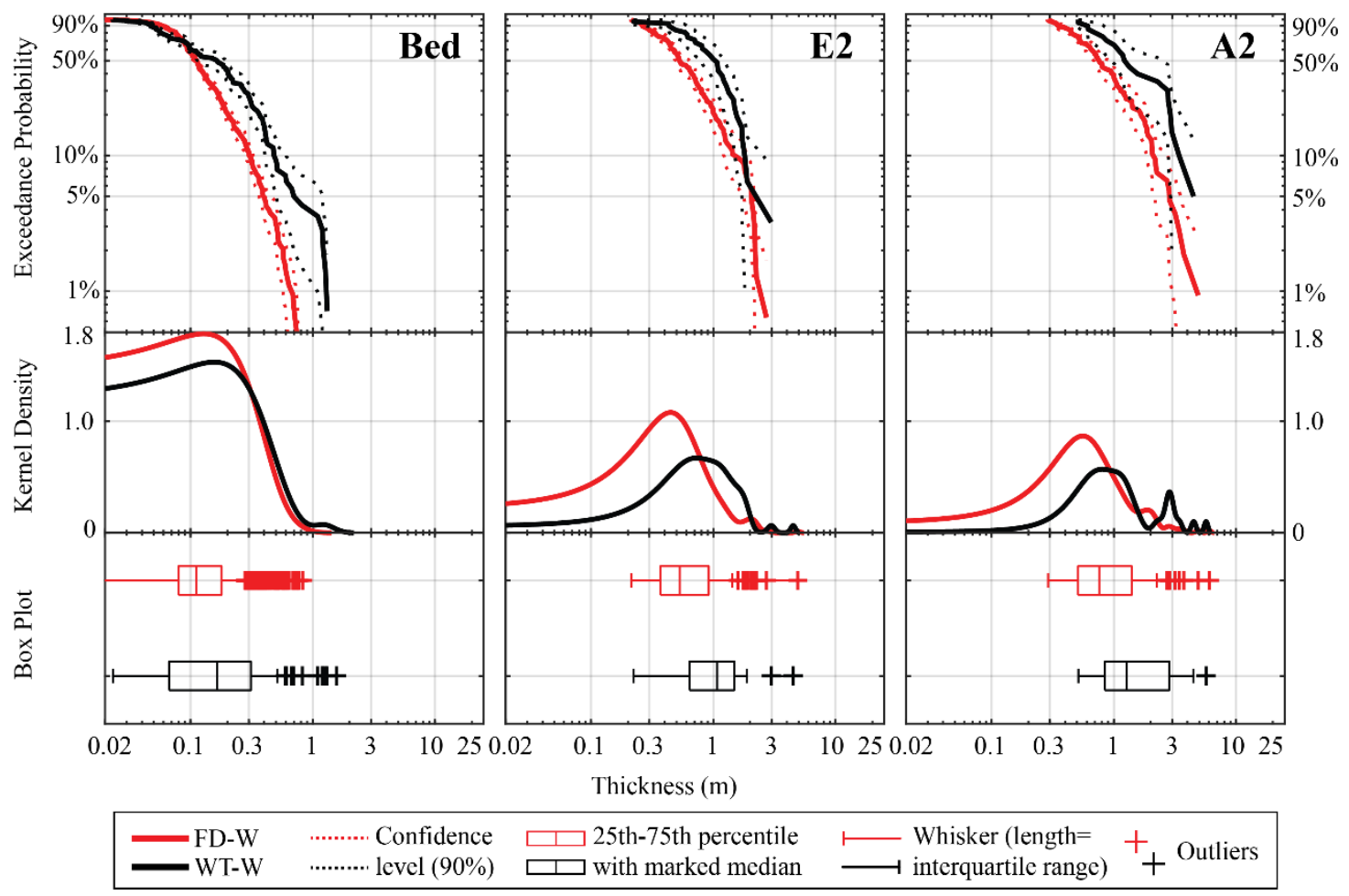

Fig. 12 Lateral variations in the distal portions of foredeep (FD-W) and wedge-top (WTW) depozones in the study area expressed in exceedance CDF, kernel density estimation, and boxplots. The WT-W shows greater thicknesses and dispersions at all hierarchical scales than the FD-E, most likely because lateral topographic confinement in WT can significantly facilitate basin-ward sediment transport and restrain the thinning of lobe deposits. 


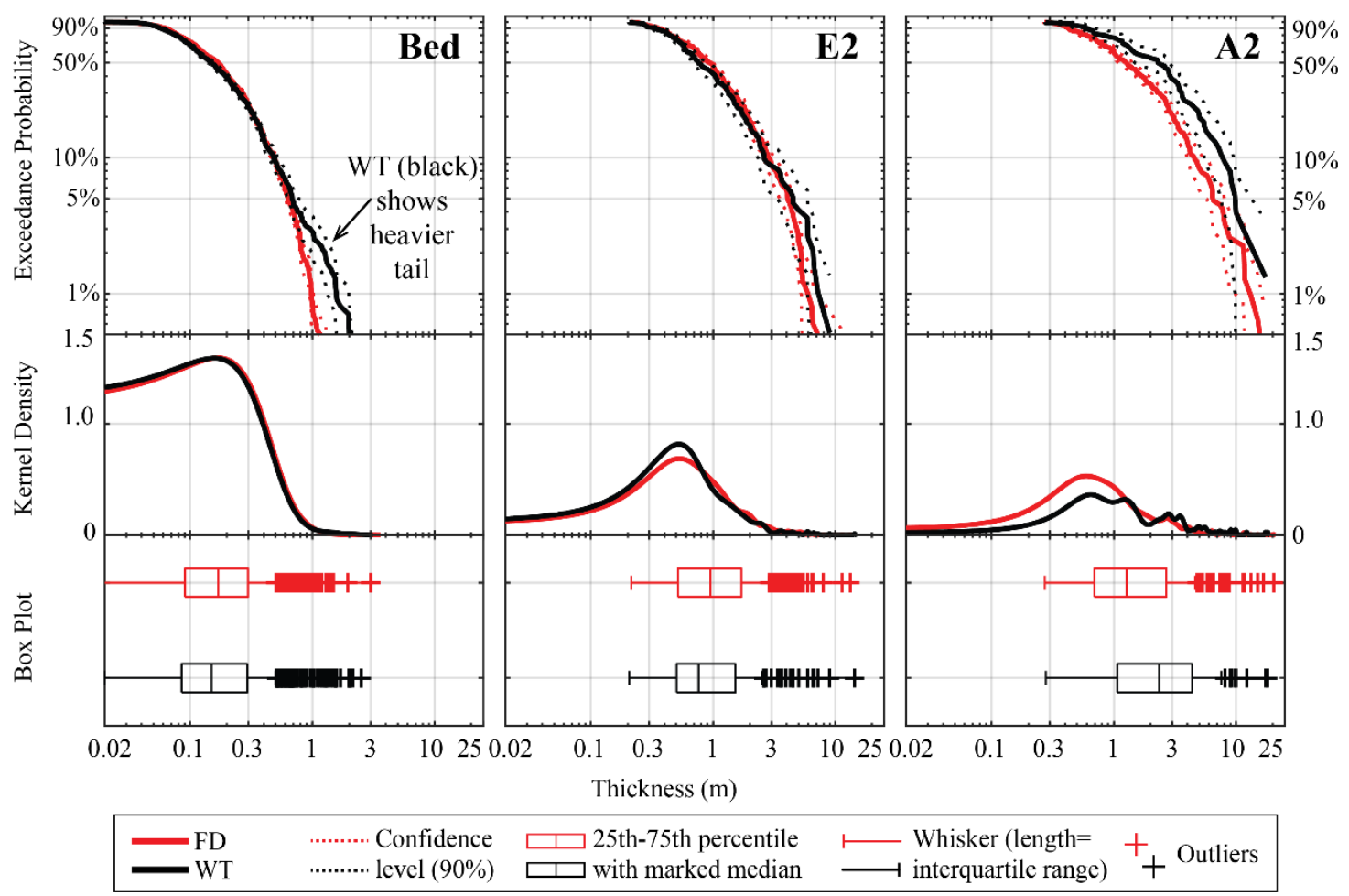

Fig. 13 Compare the entire thickness datasets in the foredeep (FD) and the wedge-top (WT) depozones, expressed in exceedance CDF, kernel density estimation, and boxplots. The thickness distributions cannot be distinguished at the lobe sandstone bed and lobe element (E2) scales with 90\% confidence level but can be distinguished at the lobe (A2) scale. The differences between the two depozones tend to increase with hierarchy because stronger lateral confinement in WT inhibited compensational stacking and result in thicker deposits with increasing hierarchical scales. 
Longitudinal trends

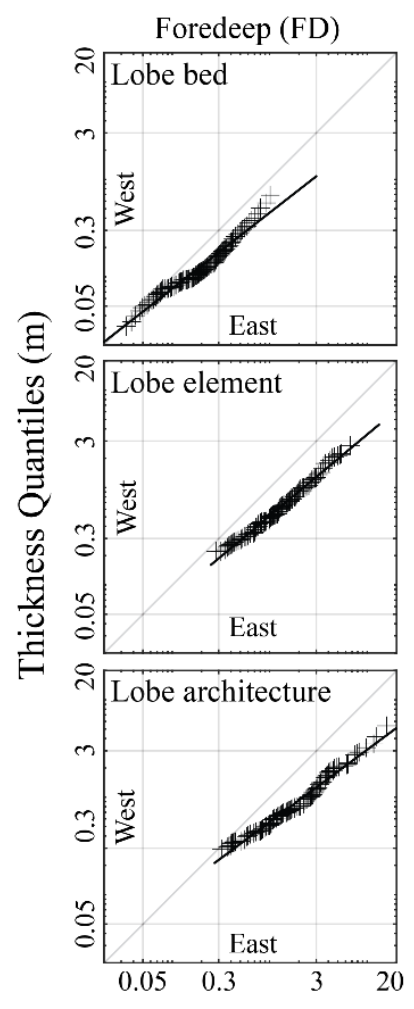

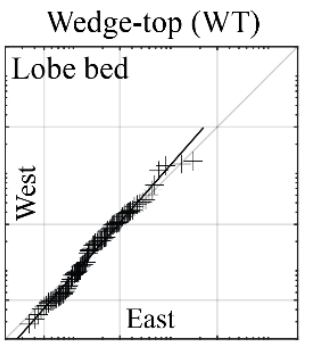
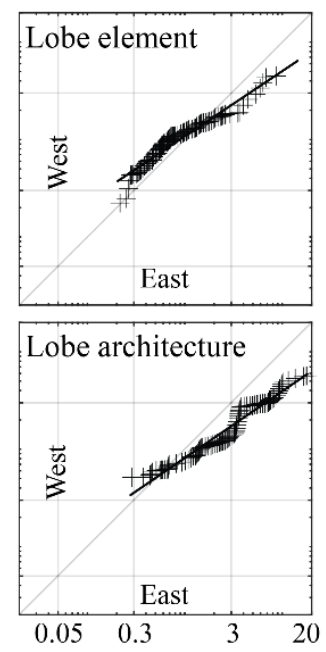

Lateral trends
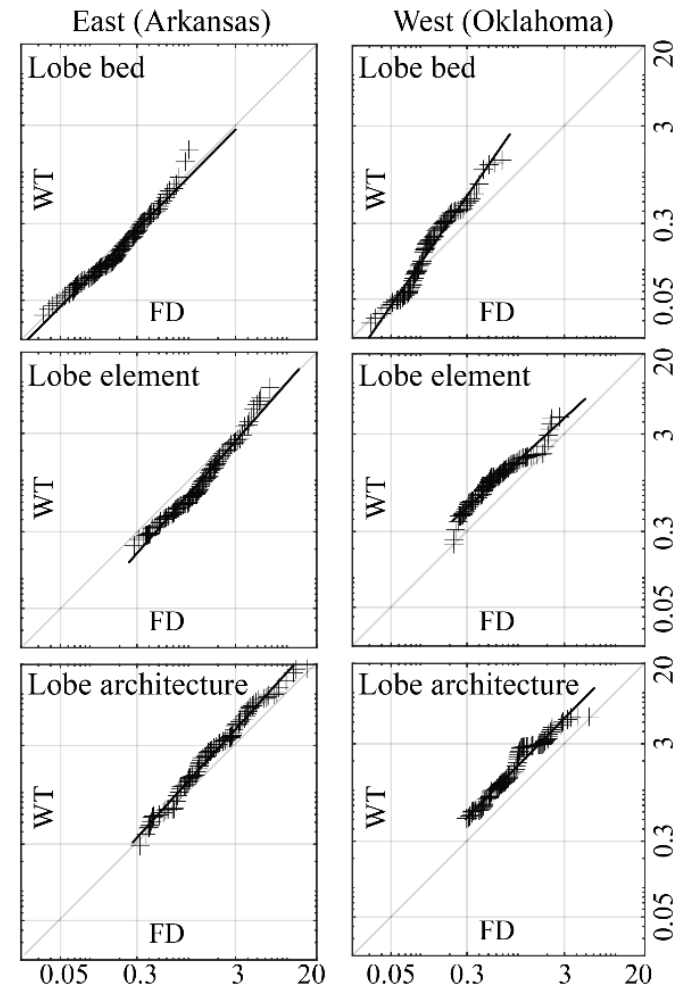

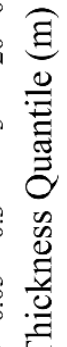

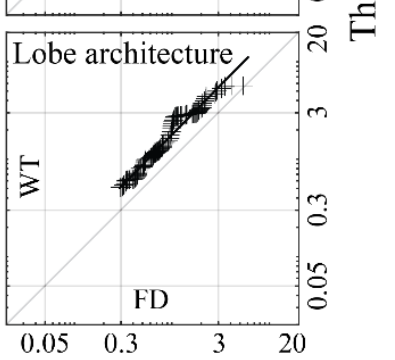

Fig. 14 Quantile-quantile plots showing the difference between longitudinal and lateral trends in the foredeep (FD) and wedge-top (WT) depozones. Each trend is illustrated with 3 hierarchical scales: bed, lobe element (E2), and lobe architecture (A2). The longitudinal trends compare the proximal (east) and distal (west) portions in each depozone. The lateral trends compare the foredeep (FD) and wedge-top in proximal and distal portions of the basin respectively. 


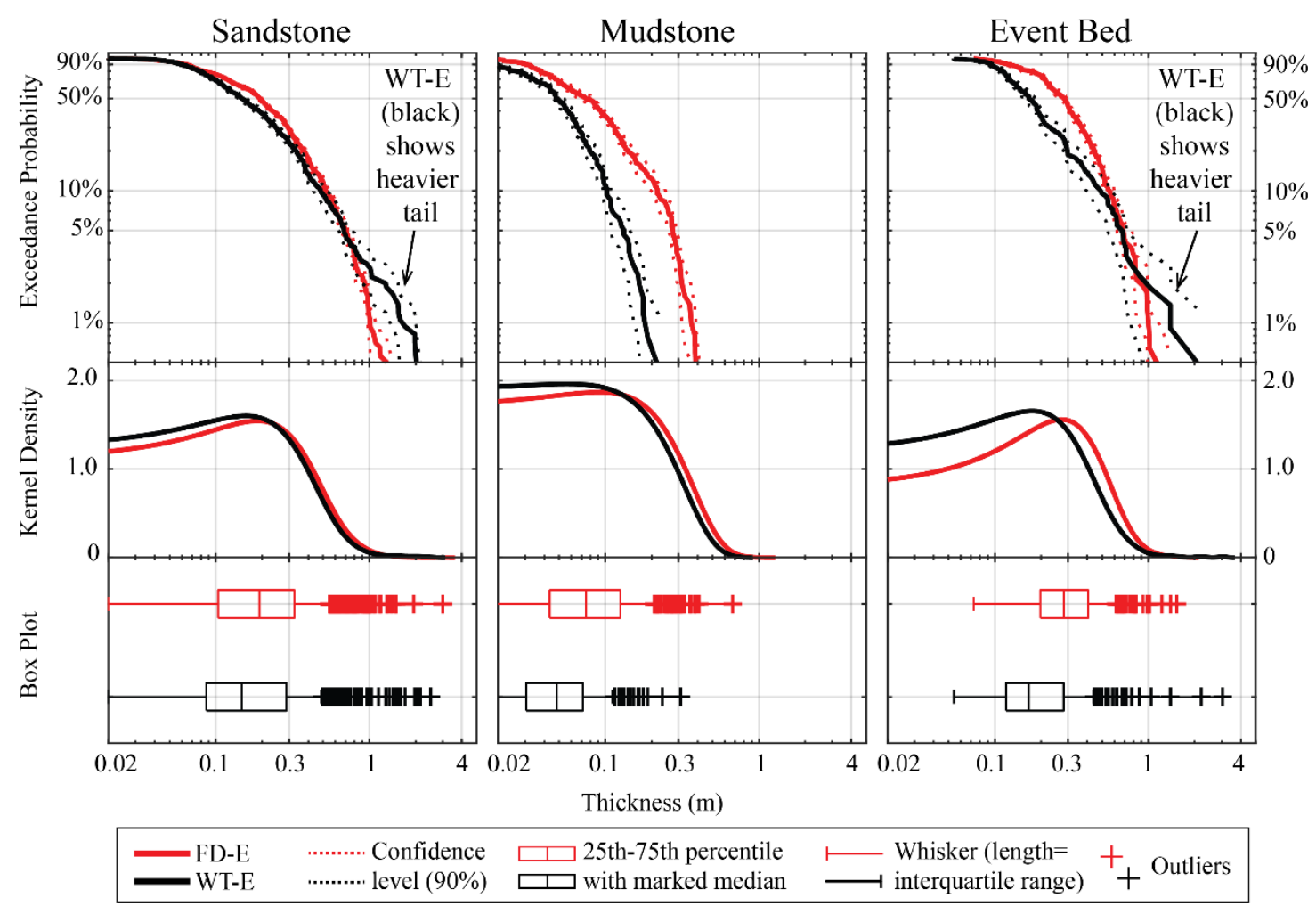

Fig. 15 Compare the thickness distributions of turbidite sandstone, mudstone, and event bed of lobe deposits, using FD-E and WT-E datasets. The heavier thick-bedded tails in both sandstone and event bed thickness datasets in WT can be explained by the higher degree of topographic confinement (Marini et al., 2016a). 


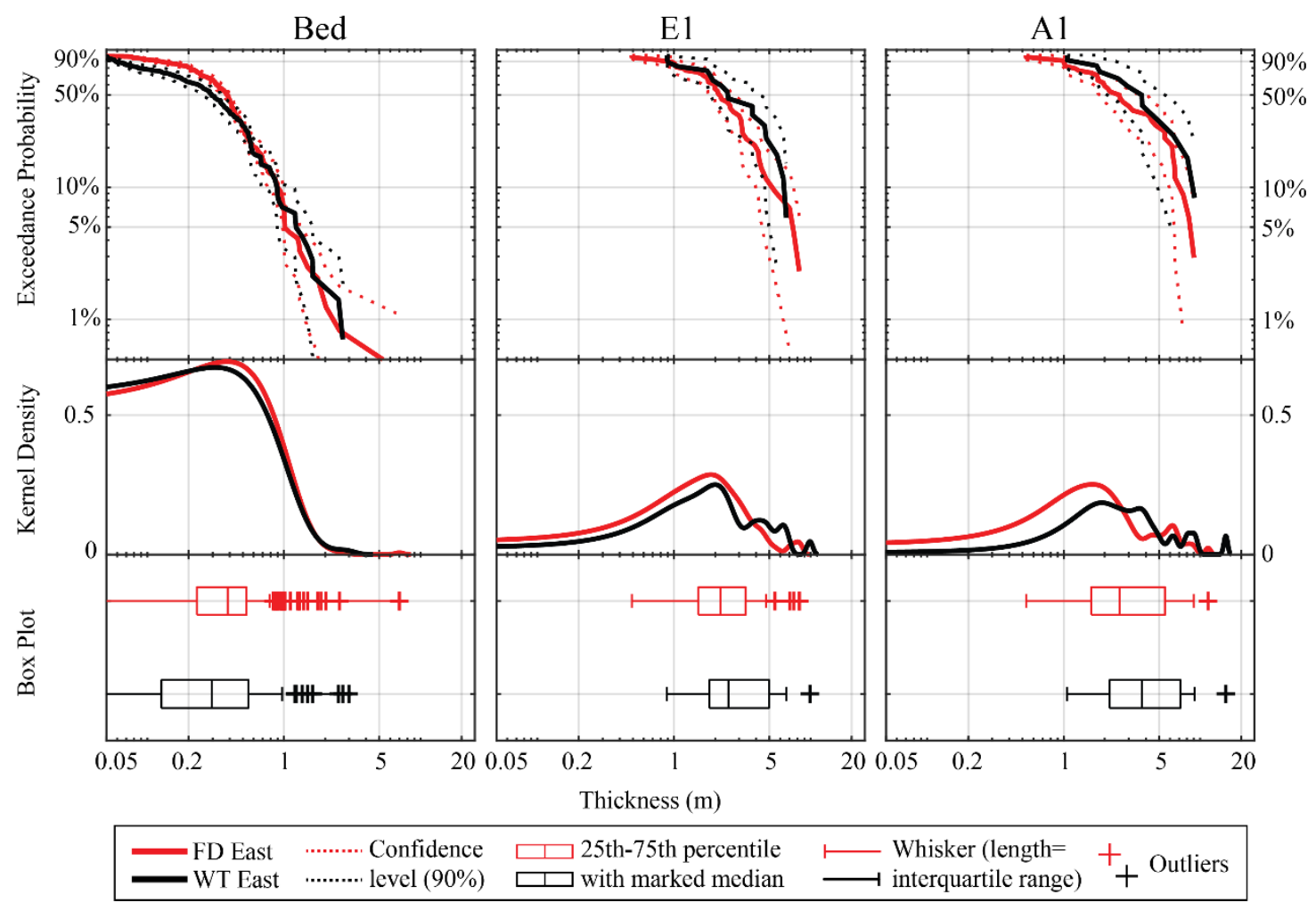

Fig. 16 Thickness distributions of the channelized deposits of the proximal foredeep (FDE) and wedge-top (WT-E) in the study area, expressed in exceedance CDF, kernel density estimation, and box plots. The 3 hierarchical scales are channel sandstone (Bed), channel element (E1), channel architecture (A1). The WT show greater thickness and dispersions than the FD at all scales. However, the largely overlapped confidence levels in all compared datasets limit the robustness of the thickness trends. The associated K-S tests results and standard errors are listed in Table 3. 


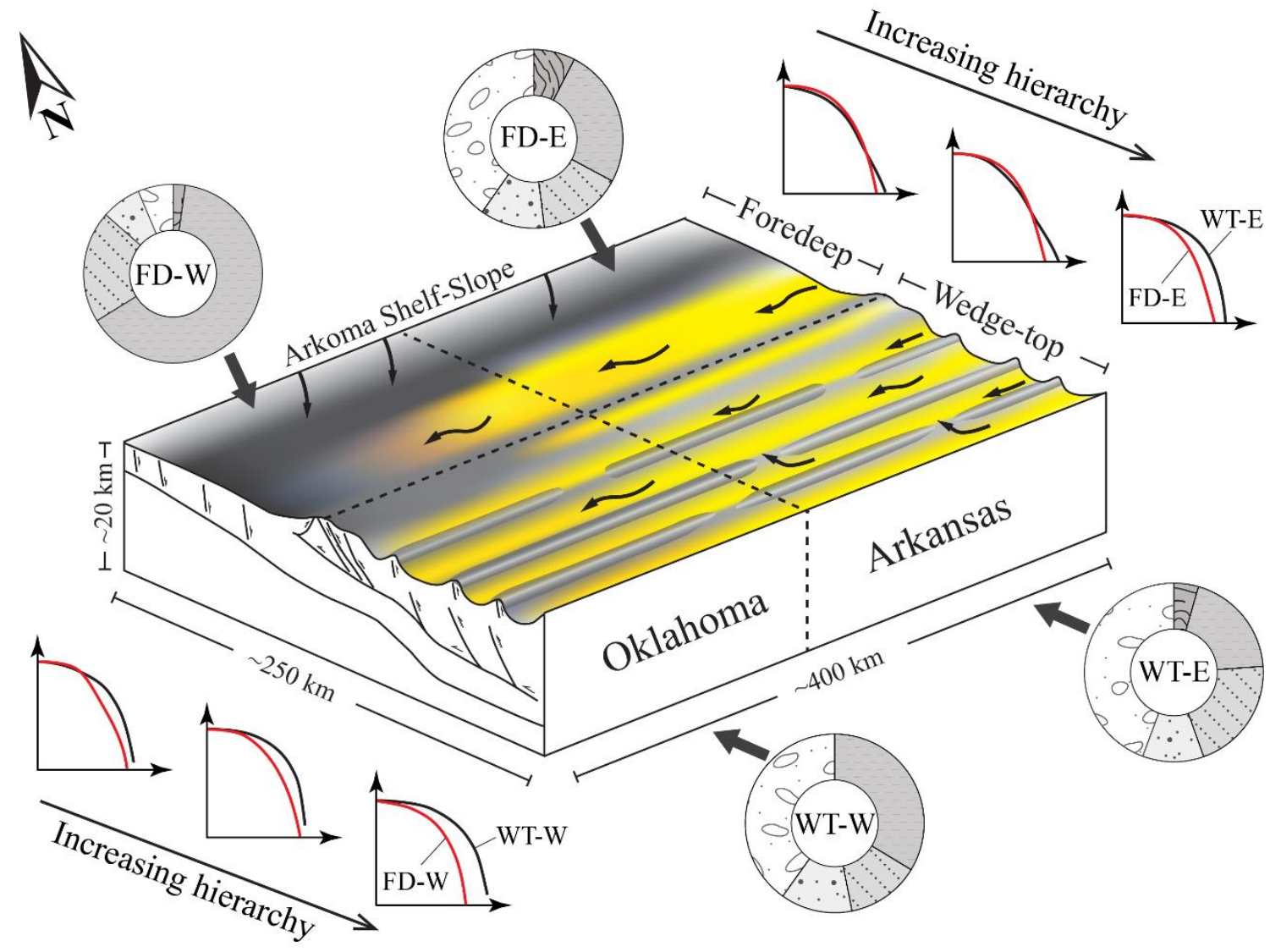

Fig. 17 Conceptual depositional model of the Lower Atoka Formation with reference to tectonic reconstruction by Arbenz (2008). The wedge-top (WT) shows stronger lateral topographic confinement than the foredeep (FD). The study area is divided into 4 subdepozones: proximal foredeep (FD-E), distal foredeep (FD-W), proximal wedge-top (WT-W) and distal wedge-top (WT-W). The basin is primarily sourced from the east, although the foredeep has additional sediment flux (probably dominantly mud) from the Arkoma Shelf-Slope to the north. The FD shows a significant longitudinal decrease in both sand-prone lithofacies and thickness of lobe deposits, whereas the FD shows little to no such variations. The lateral contrasts in thickness distributions of lobe deposits increase hierarchically. This increase can be best explained by the weaker lateral confinement and stronger compensational stacking (Straub and Pyles, 2012) in FD, which can inhibit the over-thickening of lobe deposits at higher hierarchical scales. 


\section{Tables}

Table 1

Definitions of lithofacies, architectural elements, and stratigraphic architectures in this study. Depositional processes after Bouma (1962), Lowe (1979), and Lowe et al. (1982). 


\begin{tabular}{|c|c|c|c|c|c|c|c|c|c|}
\hline \multicolumn{2}{|c|}{ Facies Hierarchy } & \multirow{2}{*}{$\begin{array}{l}\text { Thickness } \\
(\mathrm{m})\end{array}$} & \multirow{2}{*}{$\begin{array}{l}\text { Grains Size } \\
\text { fine- to } \\
\text { medium- } \\
\text { grained }\end{array}$} & \multicolumn{3}{|c|}{ Sedimentary Structures } & Bounding Surfaces & \multicolumn{2}{|c|}{ Depositional Processes } \\
\hline \multirow{6}{*}{ 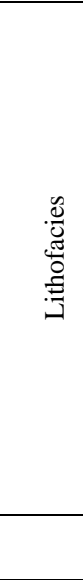 } & $\begin{array}{l}\text { F1. Massive } \\
\text { sandstone }\end{array}$ & & & \multirow{2}{*}{\multicolumn{3}{|c|}{$\begin{array}{l}\text { normally graded, structureless, or ripple- or planar-stratified; loading } \\
\text { structure common; mud clasts common near base; carbonized organic } \\
\text { detritus at bed tops; bioturbation rare } \\
\text { normally graded, planar- or sometimes cross-stratified; sole marks common; } \\
\text { loading and dewatering structures occur locally; mud clasts, organic detritus, } \\
\text { and bioturbation rare }\end{array}$}} & $\begin{array}{l}\text { erosive to sharp base; } \\
\text { sharp or gradational top }\end{array}$ & \multicolumn{2}{|c|}{$\begin{array}{l}\text { rapid suspension and traction } \\
\text { sedimentation from high-density } \\
\text { turbidity currents }\end{array}$} \\
\hline & $\begin{array}{l}\text { F2. Thick- } \\
\text { bedded } \\
\text { sandstone }\end{array}$ & $0.43-1.44$ & $\begin{array}{l}\text { very fine- } \\
\text { to fine- } \\
\text { grained }\end{array}$ & & & & $\begin{array}{l}\text { flat base without } \\
\text { significant erosion; } \\
\text { sharp or gradational top }\end{array}$ & $\begin{array}{l}\text { suspension } \\
\text { sedimentat } \\
\text { turbidity cl }\end{array}$ & $\begin{array}{l}\text { and traction } \\
\text { n from high-density } \\
\text { rents }\end{array}$ \\
\hline & $\begin{array}{l}\text { F3. Thin- } \\
\text { bedded } \\
\text { sandstone }\end{array}$ & $0.18-1.43$ & $\begin{array}{l}\text { very fine-to } \\
\text { fine- } \\
\text { grained }\end{array}$ & \multicolumn{3}{|c|}{$\begin{array}{l}\text { ripple- or planar-laminated; ripples are contorted occasionally; sole marks } \\
\text { and bioturbation abundant on bedding plane }\end{array}$} & $\begin{array}{l}\text { sharp, non-erosive base; } \\
\text { sharp or wavy top }\end{array}$ & $\begin{array}{l}\text { suspension } \\
\text { sedimentat } \\
\text { turbidity } \mathrm{cl}\end{array}$ & $\begin{array}{l}\text { ind traction } \\
\text { on from low-density } \\
\text { rents }\end{array}$ \\
\hline & F4. Mudstone & $0.06-2.19$ & $\begin{array}{l}\text { silt and } \\
\text { clay }\end{array}$ & \multicolumn{3}{|c|}{$\begin{array}{l}\text { ripple- or parallel-laminated; plant imprints, organic detritus and } \\
\text { bioturbation common on bedding plane }\end{array}$} & $\begin{array}{l}\text { sharp, non-erosive base; } \\
\text { sharp top }\end{array}$ & \multicolumn{2}{|c|}{$\begin{array}{l}\text { suspension and traction } \\
\text { sedimentation from dilute turbidity } \\
\text { currents and hemipelagic settling }\end{array}$} \\
\hline & $\begin{array}{l}\text { F5. Chaotic } \\
\text { facies }\end{array}$ & $0.24-6.95$ & $\begin{array}{l}\text { silt/clay } \\
\text { dominant, } \\
\text { some fine } \\
\text { sand }\end{array}$ & \multicolumn{3}{|c|}{$\begin{array}{l}\text { chaotic bedding; syndepositional deformation common; muddy or sandy; } \\
\text { reworked mud or sand clasts, and occasionally rafted blocks }\end{array}$} & $\begin{array}{l}\text { sharp, non-erosive base; } \\
\text { irregular or truncated } \\
\text { top }\end{array}$ & \multicolumn{2}{|c|}{ mass failure and debris flow } \\
\hline & & $\begin{array}{l}\text { Thickness } \\
(\mathrm{m})\end{array}$ & $\begin{array}{l}\text { Percent } \\
\text { sandstone }\end{array}$ & $\begin{array}{l}\text { Amalgamation } \\
\text { ratio }\end{array}$ & $\begin{array}{l}\text { Primary } \\
\text { components }\end{array}$ & Description & & & Geometry \\
\hline \multirow{4}{*}{$\frac{\overrightarrow{0}}{\frac{\overrightarrow{0}}{\Psi}}$} & $\begin{array}{l}\text { E1. Channel } \\
\text { element }\end{array}$ & $0.90-6.38$ & $99 \%$ & $81 \%$ & $\mathrm{~F} 1, \mathrm{~F} 2$, and $\mathrm{F} 5$ & \multirow{4}{*}{\multicolumn{3}{|c|}{$\begin{array}{l}\text { Significant basal erosion (decimeters to meters); top overlain by mudstone } \\
\text { sheet or lobe element } \\
\text { Flat basal contact with minor or no erosion; top overlain by thin mudstone } \\
\text { sheet or by slump } \\
\text { Flat and conformable basal and top contacts; typically } 0.4 \mathrm{~m} \text { thick; defined to } \\
\text { be at least } 0.03 \mathrm{~m} \text { thick } \\
\text { single or multiple F5; overlain by mudstone sheet or lobe element, or truncated } \\
\text { by channel element; slump in channel fill excluded }\end{array}$}} & $\begin{array}{l}\text { channel-, wedge- } \\
\text { shaped, or irregular }\end{array}$ \\
\hline & $\begin{array}{l}\text { E2. Lobe } \\
\text { element }\end{array}$ & $0.35-2.78$ & $93 \%$ & $54 \%$ & $\mathrm{~F} 1, \mathrm{~F} 2$, and $\mathrm{F} 3$ & & & & tabular \\
\hline & $\begin{array}{l}\text { E3. Mudstone } \\
\text { sheet }\end{array}$ & $0.06-2.53$ & $10 \%$ & $3 \%$ & $\mathrm{~F} 4$ and minor $\mathrm{F} 3$ & & & & tabular \\
\hline & E4. Slump & $0.36-7.39$ & $16 \%$ & $3 \%$ & F5 and minor F4 & & & & irregular \\
\hline & A1. Channel & $1.02-8.23$ & $98 \%$ & $79 \%$ & E1 and minor E3 & \multirow{2}{*}{\multicolumn{3}{|c|}{$\begin{array}{l}\text { Consists of single or multiple E1 and the thin E3 in between; overlain by lobe } \\
\text { or interlobe/interchannel } \\
\text { Consists of single or multiple E2 and the thin E3 in between; lobes are treated } \\
\text { equally regardless of internal lithofacies variation }\end{array}$}} & $\begin{array}{l}\text { channel-, wedge- } \\
\text { shaped, or irregular }\end{array}$ \\
\hline$\stackrel{0}{\Xi}$ & A2. Lobe & $0.45-5.77$ & $90 \%$ & $53 \%$ & $\mathrm{E} 2$ and minor $\mathrm{E} 3$ & & & & tabular \\
\hline 总 & $\begin{array}{l}\text { A3. } \\
\text { Interchannel / } \\
\text { interlobe }\end{array}$ & $0.41-4.30$ & $13 \%$ & $4 \%$ & E3 & \multicolumn{3}{|c|}{$\begin{array}{l}\text { Used to separate channel and lobe architectures; defined to be at least } 0.1 \mathrm{~m} \\
\text { thick, typically } \sim 1 \mathrm{~m} \text { thick }\end{array}$} & tabular \\
\hline & $\begin{array}{l}\text { A4. Mass } \\
\text { transport } \\
\text { deposit }\end{array}$ & $\begin{array}{l}0.62- \\
11.14 \\
\end{array}$ & $16 \%$ & $2 \%$ & E4 and minor E3 & \multicolumn{3}{|c|}{$\begin{array}{l}\text { consists of single or multiple E4; mostly single-element; channel (A1) filled } \\
\text { with chaotic facies excluded }\end{array}$} & irregular \\
\hline
\end{tabular}


Table 2

Descriptive statistics of thickness distributions of lobe sandstones, lobe elements, and lobe architectures entire for foredeep (FD), entire wedge-top (WT), proximal foredeep (FD-E), distal foredeep (FD-W), proximal wedge-top (WT-E), and distal wedge-top (WT$\mathrm{W})$, respectively.

\begin{tabular}{|c|c|c|c|c|c|c|c|c|c|c|c|c|c|}
\hline Hierarchy & Dataset & $\mathrm{N}$ & Sum & $\operatorname{Max}$ & Min & Mean & Median & Mode & StdDev & CoefVar & Iqr & Skew & Kurt \\
\hline \multirow{6}{*}{ Lobe Sandstone } & FD & 2616 & 603.26 & 3.01 & 0.02 & 0.23 & 0.17 & 0.07 & 0.22 & 0.93 & 0.21 & 3.46 & 29.01 \\
\hline & WT & 995 & 240.29 & 2.51 & 0.02 & 0.24 & 0.15 & 0.06 & 0.29 & 1.19 & 0.21 & 3.82 & 22.22 \\
\hline & FD-E & 1982 & 506.08 & 3.01 & 0.02 & 0.26 & 0.19 & 0.07 & 0.23 & 0.91 & 0.22 & 3.31 & 26.76 \\
\hline & FD-W & 634 & 97.18 & 0.83 & 0.02 & 0.15 & 0.11 & 0.09 & 0.12 & 0.80 & 0.10 & 2.38 & 9.76 \\
\hline & WT-E & 855 & 206.05 & 2.51 & 0.02 & 0.24 & 0.15 & 0.06 & 0.29 & 1.21 & 0.20 & 3.98 & 23.63 \\
\hline & WT-W & 140 & 34.24 & 1.57 & 0.02 & 0.24 & 0.16 & 0.05 & 0.27 & 1.11 & 0.25 & 2.58 & 10.55 \\
\hline \multirow{6}{*}{ Lobe Element } & FD & 491 & 670.30 & 13.20 & 0.21 & 1.37 & 0.95 & 0.21 & 1.37 & 1.01 & 1.19 & 3.33 & 21.19 \\
\hline & WT & 194 & 265.88 & 14.36 & 0.21 & 1.37 & 0.76 & 0.21 & 1.69 & 1.23 & 1.02 & 3.83 & 23.38 \\
\hline & FD-E & 335 & 552.10 & 13.20 & 0.25 & 1.65 & 1.18 & 0.25 & 1.53 & 0.93 & 1.27 & 3.02 & 17.68 \\
\hline & FD-W & 156 & 118.20 & 4.91 & 0.21 & 0.76 & 0.53 & 0.21 & 0.62 & 0.82 & 0.55 & 2.83 & 15.58 \\
\hline & WT-E & 163 & 228.77 & 14.36 & 0.21 & 1.40 & 0.72 & 0.21 & 1.81 & 1.29 & 1.08 & 3.65 & 21.00 \\
\hline & WT-W & 31 & 37.11 & 4.50 & 0.22 & 1.20 & 1.07 & 0.22 & 0.84 & 0.70 & 0.85 & 2.25 & 9.25 \\
\hline \multirow{6}{*}{ Lobe Architecture } & FD & 310 & 675.72 & 20.29 & 0.27 & 2.18 & 1.27 & 0.27 & 2.60 & 1.19 & 1.99 & 3.28 & 17.15 \\
\hline & WT & 76 & 259.73 & 18.12 & 0.28 & 3.42 & 2.35 & 0.28 & 3.56 & 1.04 & 3.30 & 2.17 & 8.38 \\
\hline & FD-E & 203 & 556.75 & 20.29 & 0.27 & 2.74 & 1.72 & 0.27 & 2.98 & 1.09 & 2.35 & 2.77 & 12.68 \\
\hline & FD-W & 107 & 118.96 & 6.05 & 0.29 & 1.11 & 0.76 & 0.29 & 0.95 & 0.86 & 0.89 & 2.46 & 10.80 \\
\hline & WT-E & 56 & 220.88 & 18.12 & 0.28 & 3.94 & 2.72 & 0.28 & 3.94 & 1.00 & 4.01 & 1.84 & 6.54 \\
\hline & WT-W & 20 & 38.85 & 5.69 & 0.51 & 1.94 & 1.28 & 0.51 & 1.43 & 0.74 & 2.00 & 1.12 & 3.48 \\
\hline
\end{tabular}

*StdDev-standard deviation, CoefVar-coefficient of variation, Iqr-interquartile range, Skew-skewness, Kurt-kurtosis

Table 3

K-S test results for the comparative analysis of the foredeep (FD) and wedge-top (WT) turbidite lobe deposits. 


\begin{tabular}{|c|c|c|c|c|c|c|c|c|c|c|c|c|c|}
\hline $\begin{array}{l}\text { Tests for } \\
\text { Trends }\end{array}$ & $\begin{array}{l}\text { Sample } \\
1\end{array}$ & $\begin{array}{l}\text { Sample } \\
2\end{array}$ & Hierarchy & $\begin{array}{l}\text { Sample } \\
1 \text { Size }\end{array}$ & $\begin{array}{l}\text { Sample } \\
2 \text { Size }\end{array}$ & $\begin{array}{l}\text { Standard } \\
\text { Error } 1\end{array}$ & $\begin{array}{l}\text { Standard } \\
\text { Error } 2\end{array}$ & $\alpha$ & $\mathbf{h}$ & $\begin{array}{l}\text { p- } \\
\text { value }\end{array}$ & $\begin{array}{l}\text { Test } \\
\text { statistics }\end{array}$ & Tail & $\begin{array}{l}\text { Meaning for Thickness } \\
\text { Tendency }\end{array}$ \\
\hline \multirow{3}{*}{$\begin{array}{l}\text { Test for entire } \\
\text { depozones }\end{array}$} & FD & WT & Bed & 2616 & 995 & 0.0042 & 0.0130 & 0.1 & 1 & 0.0066 & 0.06 & Smaller & Sample 1>=Sample 2 \\
\hline & FD & WT & $\mathrm{E} 2$ & 491 & 194 & 0.0620 & 0.0762 & 0.1 & 1 & 0.0613 & 0.10 & Smaller & Sample $1>=$ Sample 2 \\
\hline & FD & WT & $\mathrm{A} 2$ & 310 & 76 & 0.1474 & 0.1606 & 0.1 & 1 & 0.0013 & 0.23 & Larger & Sample $1<=$ Sample 2 \\
\hline \multirow{6}{*}{$\begin{array}{l}\text { Longitudinal } \\
\text { Trends }\end{array}$} & FD-E & FD-W & Bed & 1982 & 634 & 0.0052 & 0.0056 & 0.1 & 1 & 0.0000 & 0.30 & Smaller & Sample $1>=$ Sample 2 \\
\hline & FD-E & FD-W & E2 & 335 & 156 & 0.0836 & 0.0279 & 0.1 & 1 & 0.0000 & 0.40 & Smaller & Sample 1>=Sample 2 \\
\hline & FD-E & FD-W & $\mathrm{A} 2$ & 203 & 107 & 0.2095 & 0.0431 & 0.1 & 1 & 0.0000 & 0.37 & Smaller & Sample 1>=Sample 2 \\
\hline & WT-E & WT-W & Bed & 855 & 140 & 0.0100 & 0.0123 & 0.1 & 1 & 0.0242 & 0.12 & Smaller & Sample $1>=$ Sample 2 \\
\hline & WT-E & WT-W & $\mathrm{E} 2$ & 163 & 31 & 0.1414 & 0.0378 & 0.1 & 0 & 0.3510 & 0.14 & Smaller & Sample $1<=$ Sample 2 \\
\hline & WT-E & WT-W & $\mathrm{A} 2$ & 56 & 20 & 0.5260 & 0.0647 & 0.1 & 1 & 0.0432 & 0.31 & Smaller & Sample 1>=Sample 2 \\
\hline \multirow{6}{*}{ Lateral Trends } & FD-E & WT-E & Bed & 1982 & 855 & 0.0052 & 0.0131 & 0.1 & 1 & 0.0000 & 0.13 & Smaller & Sample 1>=Sample 2 \\
\hline & FD-E & WT-E & E2 & 335 & 163 & 0.0836 & 0.0815 & 0.1 & 1 & 0.0000 & 0.26 & Smaller & Sample $1>=$ Sample 2 \\
\hline & FD-E & WT-E & $\mathrm{A} 2$ & 203 & 56 & 0.2095 & 0.1776 & 0.1 & 1 & 0.0275 & 0.20 & Larger & Sample $1<=$ Sample 2 \\
\hline & FD-W & WT-W & Bed & 634 & 140 & 0.0049 & 0.0123 & 0.1 & 1 & 0.0000 & 0.24 & Larger & Sample $1<=$ Sample 2 \\
\hline & FD-W & WT-W & E2 & 156 & 31 & 0.0495 & 0.0378 & 0.1 & 1 & 0.0003 & 0.39 & Larger & Sample $1<=$ Sample 2 \\
\hline & FD-W & WT-W & $\mathrm{A} 2$ & 107 & 20 & 0.0923 & 0.0647 & 0.1 & 1 & 0.0115 & 0.35 & Larger & Sample $1<=$ Sample 2 \\
\hline
\end{tabular}

Table 4

Sample size, standard error, and one-sided K-S test results for the thickness distributions of channel deposits of proximal foredeep (FD-E) and proximal wedge-top (WT-E).

\begin{tabular}{|c|c|c|c|c|c|c|c|c|c|c|c|c|}
\hline Hierarchy & $\begin{array}{l}\text { Sample } \\
1\end{array}$ & $\begin{array}{l}\text { Sample } \\
2\end{array}$ & $\begin{array}{l}\text { Sample 1 } \\
\text { Size }\end{array}$ & $\begin{array}{l}\text { Sample } 2 \\
\text { Size }\end{array}$ & $\begin{array}{l}\text { Standard } \\
\text { Error } 1\end{array}$ & $\begin{array}{l}\text { Standard } \\
\text { Error } 2\end{array}$ & $\alpha$ & $\mathbf{h}$ & $\begin{array}{l}\text { p- } \\
\text { value }\end{array}$ & $\begin{array}{l}\text { Test } \\
\text { statistics }\end{array}$ & Tail & $\begin{array}{l}\text { Meaning for Thickness } \\
\text { Tendency }\end{array}$ \\
\hline Bed & FD-E & WT-E & 242 & 141 & 0.0441 & 0.0727 & 0.1 & 0 & 0.80 & 0.03 & Larger & Sample $1 \geq$ Sample 2 \\
\hline E1 & FD-E & WT-E & 43 & 17 & 0.3047 & 0.3768 & 0.1 & 0 & 0.22 & 0.24 & Larger & Sample $1 \geq$ Sample 2 \\
\hline A1 & FD-E & WT-E & 34 & 12 & 0.4725 & 0.6267 & 0.1 & 0 & 0.37 & 0.23 & Larger & Sample $1 \geq$ Sample 2 \\
\hline
\end{tabular}




\section{Supplementary Data Tables}

SDT 1. List of outcrop localities

SDT 2. Thickness and interpreted facies hierarchies of measured sections 